\title{
REVIEW
}

\section{Nitrogen sources for the growth of marine microalgae: role of dissolved free amino acids}

\author{
Kevin J. Flynn ${ }^{1, *}$ \& Ian Butler ${ }^{2}$ \\ ${ }^{1}$ Plant \& Microbial Metabolism Research Group, University College Swansea, Singleton Park, Swansea SA2 8PP, United \\ Kingdom \\ ${ }^{2}$ The Marine Biological Association of the U.K., The Laboratory, Citadel Hill, Plymouth PL1 2PB, United Kingdom
}

\begin{abstract}
Dissolved free amino acids (DFAA) form a significant proportion of dissolved fixed nitrogen in marine waters and could provide an additional source of nitrogen for the growth of marine microalgae. With the advent of DFAA analysis by HPLC, recent studies of algal physiology, and an increased awareness of potential experimental errors, doubts are cast over the conclusion that marine microalgae are not net users of DFAA. Results obtained by testing the use of a few amino acids cannot be extrapolated; the full range of amino acids should be used in field experiments. A high rate of uptake of any one amino acid is not to be expected. It is more probable that a simultaneous uptake of several amino acids will occur at a lower rate. It is essential that environmental conditions be taken into account in interpretation of results from field experiments. Results from laboratory and field studies suggest that maximum rates of DFAA uptake would occur in dark conditions in waters depleted of dissolved inorganic nitrogen. Turbid estuaries and coastal waters would also be environments likely to induce a significant uptake of amino acids, because levels of DFAA in such waters aro relativaly hig $\mathrm{y}^{2}$ and the periods of enforced darkness due to turbidity are likely to induce the development of microalgal amino acid uptake systems.
\end{abstract}

\section{INTRODUCTION}

Over the last few decades there have been 2 longrunning debates about the control of marine primary production. The first of these is the agricultural model versus predator-prey model controversy, as described by Cushing (1975). The agricultural model describes a system in which primary production is essentially nutrient limited and the standing crop of algae is grazed by zooplankton. The predator-prey model, however, says that predation limits primary production. A key question is what type of nutrients support primary production in summer in temperate waters, for although the concentrations of inorganic nutrients (nitrate and phosphate) are very low at this time of year the concentration of organic nutrients are higher in summer than in winter (Butler et al. 1979). If these organic compounds can be used by phytoplankton

- Addressee for correspondence then primary production is more likely to be limited by predation.

A major difference between the agricultural model and the natural marine ecosystem is that the model cannot adequately explain species succession; the model more closely resembles a unialgal culture grown under optimum conditions. In contrast, the predator-prey model, superimposed on seasonal variations of temperature, illumination and nutrient availability, will allow species succession; grazing alone can affect species succession (Ryther \& Sanders 1980).

The second debate concerns which nutrient, nitrogen or phosphorus, is most likely to limit phytoplankton growth (if either). This debate stems from the work of Redfield (1958) who argued that any nitrogen deficit in the oceans could be met by the biological fixation of atmospheric nitrogen. This idea has been refuted by Ryther \& Dunstan (1971), and by other biologists, who presented data and arguments for the contention that inorganic nitrogen, not inorganic phosphorus, is limit- 
ing. Generally biologists favour nitrogen limitation, and geochemists favour phosphate limitation, but on a local scale the availability of these nutrients will depend on rates of water exchange and of biochemical processes leading to nutrient replenishment or regeneration (Smith 1984, Smith et al. 1986). Another factor has been introduced by Jackson \& Williams (1985) who suggest that the inclusion of dissolved organic nitrogen (DON) and dissolved organic phosphorus (DOP) into the equations improves the Redfield argument. However, whilst the possible use of DOP by microalgae, involving the development of alkaline phosphatase by P-deplete algae, is acknowledged (Myklestad \& Sakshaug 1983, Degobbis et al. 1986, Heath 1986), the use of components of DON (other than urea) by these organisms is still considered to be negligible.

The question of the utilization of DON by marine microalgae is thus a factor in both the agricultural vs predator-prey model debate and the nitrogen vs phosphorus (Redfield ratio) debate. To quote from a report from a Royal Society Study Group (1983): 'An important question which has not been resolved is whether during summer, when inorganic $N$ concentrations in the euphotic zone are low, the phytoplankton utilize as a source of $\mathrm{N}$ at least part of the large quantities of dissolved organic $\mathrm{N}$ which are present.' If components of DON are used by phytoplankton then it may explain why natural populations of phytoplankton do not always show the symptoms of $\mathrm{N}$-limitation expected from the low quantities of inorganic- $N$ in their surroundings (Goldman et al. 1979). The aim of this review is not to provide an exhaustive examination of the role of various sources of nitrogen in the growth of marine microalgae, for others have filled this need (Morris 1980, Platt 1981, Carpenter \& Capone 1983), but rather to re-examine the potential role of free amino acids in this process.

In this work 'transport' describes the processes of solute passage through the plasma membrane, while 'assimilation' describes the incorporation or catabolism of the solute within the cell. Often these processes are not, or cannot, be separated. This is true especially for studies in which measurements have been made of solute disappearance from the medium, and for incubations of longer than, say, 30 min (including all field studies) after which assimilatory processes are most likely to affect transport by feedback. 'Uptake' is therefore used to include transport and assimilation/ accumulation. The 'intracellular amino acid pool' is a descriptive term for subcellular compartments (principally cytosol and vacuole) in which amino acids are accumulated prior to catabolism or incorporation. Because the study of algal amino acid uptake systems is incomplete, some of the examples given are of freshwater species.

\section{SOURCES OF DISSOLVED FIXED NITROGEN PRESENT IN THE SEA}

Before examining the possible use of components of dissolved fixed nitrogen by phytoplankton, it is appropriate to consider the sources available, their concentrations, and temporal variability. The data presented are from the euphotic zone at Station E1 in the western English Channel and are a synthesis from several sources; they were not collected simultaneously. Whilst the absolute values may vary from year to year, the trends and general concentration ranges are typical for this station where measurements of production have been made for over 50 yr (studies were made at this station to support the agricultural model in the twenties; Atkins 1923). The data illustrate the classic picture for coastal temperate waters of spring and autumn production maxima. Such data are not typical of open ocean waters in which levels of nutrients and production are usually much lower. The data are from Boalch et al. (1978), Butler et al. (1979) and Braven et al. (1984), but unless otherwise indicated the other examples are not from Station E1, although the processes will, to a greater or lesser extent, also apply to this station. Various rank correlations have been performed on these data and on those from other sources. The results are summarized in Table 1 and, although the significance of some are questionable, some interesting points do emerge and are discussed in the section 'Dissolved free amino acids' (pp. 283-286).

\section{Nitrate}

Nitrate is the dominant form of dissolved nitrogen in the winter but its concentration falls during the spring bloom and reaches a minimum in mid summer (Fig. 1a \& 3). Regeneration is affected by bacterial nitrification of more reduced forms. During the summer, nitrification at the base of the pycnocline, below the chlorophyll maximum, may be an important source of regenerated nitrate for the growth of the dinoflagellate Gonyaulax tamarensis in the Gulf of Maine (Holligan et al. 1984). However, the dramatic increases in the concentration of nitrate are caused by advection in autumn when the thermocline breaks up. After August, concentrations rise despite the occurrence of an autumn bloom which seems to have little effect on the amounts of nitrate present (Fig. 1a). The concentration of nitrite is normally less than $5 \%$ of that of nitrate.

\section{Ammonium}

Ammonia is the primary form of fixed nitrogen, formed by the reduction of $N_{2}$. The total amount of $N_{2}$ 


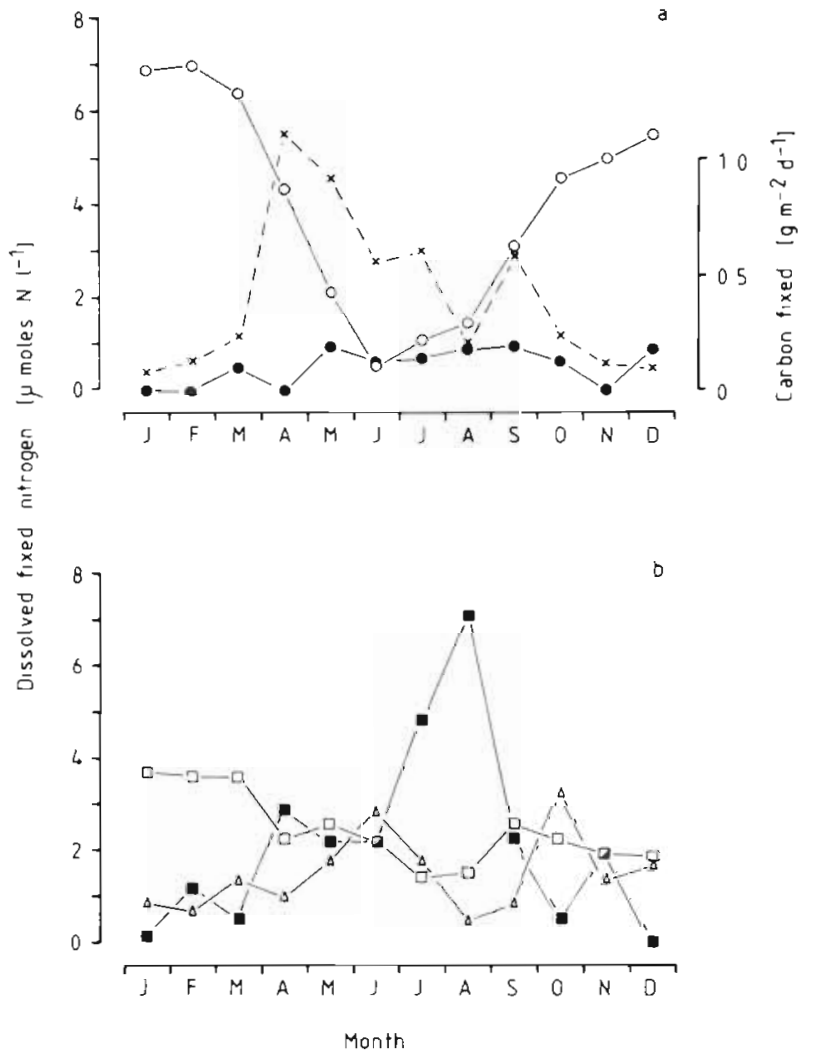

Fig. 1 Levels of primary production and concentrations of dissolved fixed nitrogen in the euphotic zone in the western English Channel over the year. (a) Primary production ( $x--x)$,

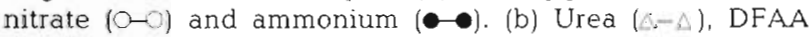
$(\square-\square)$, and uncharacterized DON (-

fixed by marine cyanobacteria is unknown, but it is thought to be of importance in some oligotrophic areas (see Carpenter 1983 for review). Ammonium is the major excretory product of animals in the marine environment (Corner \& Newell 1967, Corner et al. 1972, Jawed 1973, Corner et al. 1976) and of holozoic dinoflagellates (Brockmann et al. 1977). Although ammonium is usually present at low levels throughout the year (Fig. 1a \& 3), this may belie its importance due to the rapid use of regenerated ammonium (Glibert 1982, Glibert et al. 1982b, Goldman et al. 1985, Verity 1985). Net zooplankton alone may regenerate $13 \%$ of the ammonium requirement of phytoplankton (Dagg et al. 1982). Ammonium is also regenerated by the bacterial reduction of nitrate and nitrite, and by the deamination of organic nitrogenous compounds.

\section{Urea and trimethylammonium oxide}

Urea is the major excretory product of mammals and birds, but not of zooplankton and fish. The major forms of nitrogenous waste from teleosts are ammonium (much of which is continuously exchanged at the gills) and trimethylammonium oxide (TMAO) (Forster \& Goldstein 1969); urea may form only $10 \%$ of teleost excretion. Arginine is an essential amino acid which would be lost in the synthesis of urea. The use of TMAO is not normally considered for algal nutrition, although bacteria are known to be able to utilize it (Colwell \& Liston 1961).

About $10 \%$ of $\mathrm{N}$-excretion by zooplankton is as urea (Jawed 1969, Corner et al. 1976, Turley 1985) but this proportion varies depending on the type of zooplankters present. Although arginine is an essential amino acid for most invertebrates (Roman 1983), phytoplankton contain a greater proportion of arginine than zooplankton and the excess is removed by argininase with the formation of urea and ornithine. Herbivores therefore excrete a greater proportion of urea than carnivores (Bidigare 1983) and hence the availability of regenerated urea will depend on the predominance of herbivores. There will also be a terrestrial input from sewage outfalls but this is probably only of local importance (Remsen 1971).

The concentration of urea at Station E1 is higher than that of ammonium but generally lower than that of nitrate except in mid-summer when levels of nitrate are at their lowest (Fig. 1b \& 3). Peaks of urea concentration appear to correlate with maximum numbers of zooplankton which follow blooms of algal growth in spring and early autumn.

\section{Dissolved free amino acids}

Dissolved free amino acids (DFAA) are products of protein hydrolysis by bacterial proteases and may also be released by healthy as well as senescent phytoplankton (Hellebust 1965, Fogg 1966, Williams \& Yentsch 1976, Jolley \& Jones 1977, Mague et al. 1980, Hammer \& Brockmann 1983, Carlucci et al. 1984). Whilst the degradation of detritus by bacteria may provide a continual flow of DFAA to the environment (Litchfield 1973), there is some doubt as to the availability of amino acids released by proteolytic activity to any organisms other than the proteolytic bacteria themselves (Amano et al. 1982). Hollibaugh \& Azam (1983) suggest that amino acids released by proteolytic activity are used preferentially and do not completely mix with those amino acids in the water column. There is also a release of amino acids from invertebrates as part of their N-excretion (Andersson et al. 1985) and in response to changes in salinity; amino acids have a function in osmoregulation in invertebrates (Webb et al. 1971). Amino acid excretion by the copepod Eucalanus pileatus appears to occur in pulses (Gardener \& Paffenhöfer 1982). The amount of nitrogen 
excreted as amino acids from zooplankton can amount to $25 \%$ of total (Webb \& Johannes 1967) although a Jevel of $10 \%$ may be more typical (Bidigare 1983). This is a similar proportion to that excreted as urea.

Caution should be exercised when referring to the quantity and quality of DFAA in seawater (and also to levels of free amino acids extracted from cells and excreted by algae and zooplankton) measured without

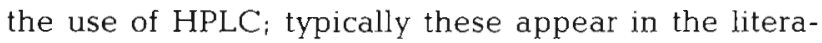
ture before 1980. Before the development of analysis by HPLC (Lindroth \& Mopper 1979, Evens et al. 1982) samples were typically desalted and concentrated before analysis; such procedures can result in errors (Dawson \& Gocke 1978, Dawson \& Mopper 1978). It is now known that samples should be analysed within hours and not stored. Using HPLC a full analysis of
DFAA in one sample is performed in less than $30 \mathrm{~min}$, measuring concentrations of individual amino acids to picomolar levels. This method of analysis has been reviewed recently by Mopper \& Dawson (1986).

There is considerable variation in the concentrations of individual amino acids, but levels of some are always very low (e.g. arginine) while others (e.g. glycine) are usually present at higher levels. Ornithine is often one of the most abundant amino acids, and has been reported to constitute up to $70 \%$ of DFAA in the Celtic Sea (Williams \& Poulet 1986); at Station E1 this figure is $11 \%$ averaged over the year (Braven et al. 1984). The proportions in which amino acids occur in seawater do not resemble the proportions in living tissue (Table 1e) either because some are preferentially taken up (Amano et al. 1982), or because release

Table 1. Results of correlations between presence of dissolved fixed nitrogen, DFAA, and other factors. Rank correlations (after Spearman) were performed using the data from Boalch et al. (1978), Butler et al. (1979) and Braven et al. (1984) and other sources as indicated below. Conclusions (0) and criticisms or problems ( are given; further comment will be found in the text

\begin{tabular}{|c|c|c|}
\hline Test & Result (significance level) & Comments \\
\hline \multicolumn{3}{|l|}{ (a) $1^{\circ}$ production } \\
\hline$v S \mathrm{NO}_{3}^{-}$ & -ve correlation $(95 \%)$ & \\
\hline vS $\mathrm{NH}_{4}^{+}$ & No correlation & (o) $\mathrm{NO}_{3}^{-}$vs $\mathrm{NH}_{4}^{+}$-ve at $90 \%$ \\
\hline vs urea & No correlation & \\
\hline vs $\mathrm{NH}_{2}-\mathrm{N}$ & No correlation & (0) $\mathrm{NO}_{3}$ vs $\mathrm{NH}_{2}-\mathrm{N}+$ ve at $95 \%$ \\
\hline VS otner DUN & +ve correlation $(90 \%)$ & \\
\hline (b) Urea vs ORN & - ve correlation $(80 \%)$ & $\begin{array}{l}\text { (O) Either use of ORN differs from that of urea, or } \\
\text { processes other than excretion involved in } \\
\text { release }\end{array}$ \\
\hline (c) DFAA vs DFAA & $\begin{array}{l}30 \% \text { of tests +ve }(95 \%) \text {; others no } \\
\text { correlation }\end{array}$ & $\begin{array}{l}\text { ASP, GLU, ABU, GLY \& LEU appear to form } \\
\text { a group } \\
\text { ( ) Night-time values unknown }\end{array}$ \\
\hline (d) DFAA proportions & $\begin{array}{l}\text { Oct \& Nov differ from others } \\
\text { Other months + ve correlation }(95 \%)\end{array}$ & $\begin{array}{l}\text { (O) Difference possibly due to breakdown of } \\
\text { DON in Aug \& Sep } \\
\text { (-) Night-time values unknown } \\
\text { (-) After removal of group ASP/GLU/ABU/GLY/ } \\
\text { LEU Jun, Aug, Oct \& Nov differ with } 50 \% \text { of } \\
\text { other months }\end{array}$ \\
\hline (e) DFAA vs algal AA & No correlation & $\begin{array}{l}\text { (O) Production \&/or use of DFAA not in pro- } \\
\text { portion to AA composition in algae (Cowey \& } \\
\text { Corner 1966) }\end{array}$ \\
\hline (f) DFAA vs algal excretion & $\begin{array}{l}\text { Mar }(95 \%) \\
+ \text { ve Feb, Mar, July, Sep, \& Nov }(90 \%)\end{array}$ & $\begin{array}{l}\text { (0) Daytime DFAA may correlate with algal } \\
\text { release (Hammer \& Brockmann 1983) } \\
\text { ( Night-time values unknown; methods of } \\
\text { Hammer \& Brockmann (filtration) may have } \\
\text { given errors }\end{array}$ \\
\hline (g) DFAA vs bacterial threshold & $\begin{array}{l}\text { +ve correlation for all months except } \\
\text { Aug \& Oct }(95 \%)\end{array}$ & $\begin{array}{l}\text { (o) Bacterial action may determine DFAA com- } \\
\text { position (Amano et al. 1982) } \\
\text { (-) Night-time values unknown; methods of } \\
\text { Amano et al (desalting \& concentration) may } \\
\text { give errors }\end{array}$ \\
\hline (h) DFAA vs algal preference & $\begin{array}{l}\text { - ve correlation for Mar \& Jul }(90 \%) \text {. } \\
\text { All values - ve }\end{array}$ & $\begin{array}{l}\text { DFAA at low conc generally those preferred } \\
\text { (Lu \& Stephens } 1984-\text { protein AA) } \\
\text { () Preferences in dark, \& night-time levels of } \\
\text { DFAA unknown }\end{array}$ \\
\hline
\end{tabular}


into the environment by processes other than decay are more important. The high levels of the non-protein amino acid ornithine is an example, but its presence does not appear to correlate with that of urea (the other product of arginine catabolism) at Station E1 either (Table 1b). However, its presence has been associated with grazing activity at other stations (Palumbo et al. 1983, Hammer \& Kattner 1986, Williams \& Poulet 1986). Concentrations of individual amino acids, and of total DFAA, vary with time of day, season, depth and location (Mopper \& Lindroth 1982, Braven et al. 1984, Poulet et al. 1984, Williams \& Poulet 1986). A particularly striking difference is that concentrations of DFAA fall during the night and rise during the day (Mopper \& Lindroth 1982, Carlucci et al. 1984, Williams \& Poulet 1986).

There has been some doubt as to the availability of free amino acids because of sorbtion onto surfaces and complexing with metals (Dawson \& Gocke 1978), but unless suspended clays are present this is probably not significant (Jørgensen \& Søndergaard 1984). Because of the preanalysis treatment of samples for HPLC, amino acids attached to clays may not be detected by this method.

An additional problem is the proportion of $D$ and $L$ isomers of amino acid present in DFAA. It has been suggested that bacterial racemization of L-amino acids may reduce the availability of amino- $\mathrm{N}$ for eukaryotes (Lee \& Bada 1977). The data of Lee \& Bada (1977) for the enantiomeric ratios of a few dissolved amino acids isolated from seawater and phytoplankton suggest an enrichment of $\mathrm{D}$-isomers in the seawater, but even so average values appear to be in the region of only $10 \%$ $\mathrm{D}$-isomers in the water. It remains to be seen if the application of new methods of analysis (Mopper \& Dawson 1986) will corroborate this value, as the methods of sample storage and analysis used by Lee \& Bada (1977) may have produced errors.

At Station E1, concentrations of DFAA are maximal in winter but fall in spring (correlating with the fall in nitrate: Table 1a) and after fluctuating reach a minimum in August (Fig. 1b). Levels of different groups of amino acids are shown in Fig. 2a; concentrations of sulphur-amino acids were below levels of detection. It should be noted that amino acid transport into algae is by porters specific to such groups (see 'Amino acid porters', p. 294-296). The spring and autumn peaks for aliphatic neutral amino acids (Fig. 2a) appear to correlate with those of urea (Fig. 1b). Fig. 2b shows how the amounts of individual basic amino acids varied through the year.

The positive correlation between the concentration of nitrate and DFAA (Table 1a) suggests that, as levels of nitrate fall, the excretion of DFAA by algae decreases and/or rates of uptake of DFAA by microbes
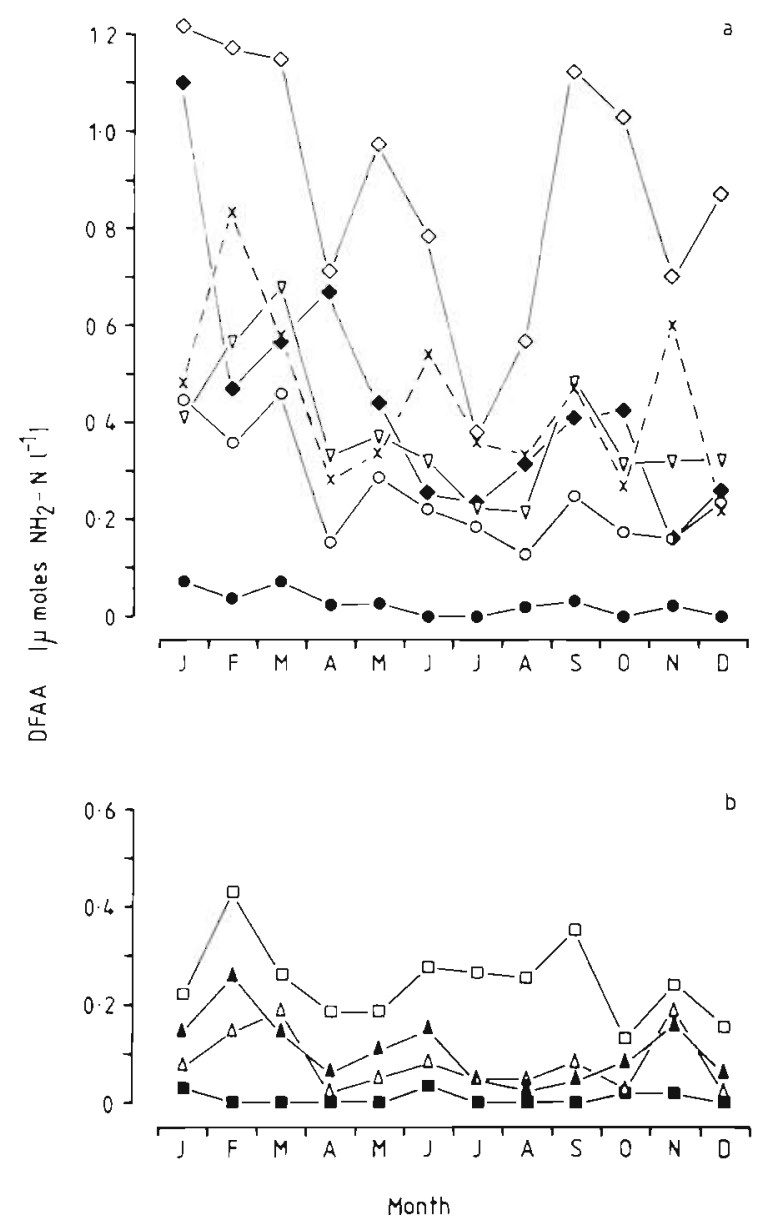

Fig. 2. Concentrations of DFAA in the euphotic zone in the western English Channel over the year. (a) Acidic $(\circ-0)$, amidic $(\bullet-\bullet)$, aliphatic hydroxy $(\nabla-\nabla)$, aliphatic neutral $(\diamond-\diamond)$, aromatic $(\bullet-\bullet)$, and basic amino acids $(x--x)$. (b) Basic amino acids: ARG $(\bullet)$, HIS $(\mathbf{\Lambda}), \operatorname{LYS}(\Delta)$, and ORN ( $\square)$

increase. This is consistent with the correlation between the proportions of amino acids in DFAA and in algal exudate in March (Table 1f), and the positive correlation between the composition of DFAA and the threshold levels for amino acid utilization by marine bacteria (Table $1 \mathrm{~g}$ ). Together with the consistency in the proportions of DFAA throughout the year, except in autumn (Table 1d), these results suggest that the levels of DFAA which we measure are for the most part residual levels, and that amino acids present at very low concentrations are as a result of microbial (bacterial and algal) activity. The problem of differentiating between production and utilization of DFAA can also occur in laboratory experiments. In the work of Andersson et al. (1985), microflagellates were fed with live bacteria which, although they could not divide, did remove DFAA from the medium. As a result, although increased DFAA concentrations were measured, the proportions of each amino acid remained the same as those present in control (bacteria only) 
cultures for the first $24 \mathrm{~h}$. By $52 \mathrm{~h}$, ornithine was more dominant and alanine less so, but the composition is statistically little different from $24 \mathrm{~h}$ and the data still do not demonstrate clearly the quantity or quality of microflagellate DFAA exudate.

The only data for algal amino acid preference are those of Lu \& Stephens (1984) and these do show a degree of negative correlation with the proportions of DFAA in the water column in 2 mo (Table $1 \mathrm{~h}$ ). Interestingly, the marine bacteria tested by Amano et al. (1982), and the diatoms Phaeodactylum tricornutum (Lu \& Stephens 1984) and Melosira mediocris (Ming \& Stephens 1985) were capable of removing some amino acids completely; there is no suggestion from these results that bacteria could 'out-compete' with algae for DFAA. Unfortunately data for the quantity and quality of DFAA at night over the course of the year are not available; algae are more likely to use DFAA at night than in daylight (see 'Effect of darkness' p. 293).

\section{Unknown components of DON}

Much of the remaining DON exists in the form of amino-sugars, purines, pyrimidines, peptides, polypeptides and proteins, many of which will be products of decay but some may be leaked from living cells (Newell et al. 1972).

Purines and pyrimidines are products of nucleic acid degradation. Hypoxanthine and guanine have been identified as the major end product of purine metabolism in a marine ciliate (Soldo et al. 1978) forming refractile bodies within the animal. Guanine is the principal constituent of teleost scales and is also present in the walls of fish swim bladders (Alexander 1975). The concentrations of these compounds in seawater have not been measured; techniques are being developed, but uric acid and, to a lesser extent, xanthine are unstable in seawater (Antia \& Landymore 1974). Levels are likely to be low due to the low solubility (both in terms of rate of dissolution and of maximum concentration) of these compounds which probably ensures that much enters the benthic detrital food web after the particles have sunk through the water column.

In contrast with the concentrations of the other forms of dissolved nitrogen at Station E1, the highest levels of the uncharacterized components were recorded in August with the lowest concentration occurring in winter (Fig. 1b). This is positively correlated with levels of primary production (Table 1a). The rapid decline in the presence of DON in autumn is marked by a change in the composition of DFAA (Table 1d), although the advection which results in an increase in nitrate is probably also partly responsible for the fall in levels of DON.

\section{Conclusions}

The over-riding seasonal trend of the lower forms of dissolved nitrogen (nitrate, ammonium, urea and amino acids, of which amino- $\mathrm{N}$ constitutes about $30 \%$ at all times at E1: Fig. 3) is of a high in winter and a low in summer. However, even in mid-summer there is almost as much dissolved nitrogen present in the form of ammonium, urea and amino acids as there is as nitrate in winter. Provided that these forms of nitrogen are actually available for the growth of phytoplankton then there is no longer the apparent lack of nitrogen in the water column as suggested by an examination of

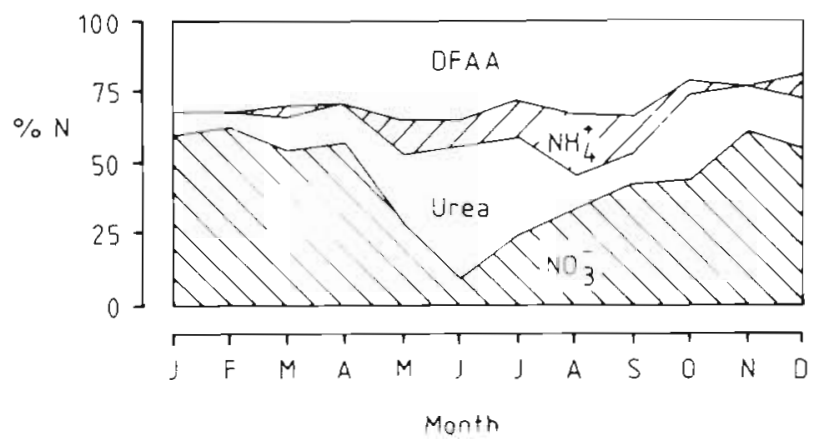

Fig. 3. Proportions of characterized dissolved fixed nitrogen present as DFAA, ammonium, urea and nitrate in the euphotic zone in the western English Channel over the year

nitrate alone. It is interesting to note that the concentration of total dissolved nitrogen remains remarkably constant throughout the year in the western English Channel (Butler et al. 1979).

It is important to appreciate that the concentration of a particular nitrogen source need not be indicative of the extent to which it is utilized by phytoplankton. The detection of low levels can be used to support 2 arguments; either there is too little present to support growth and therefore it is an insignificant nitrogen source, or because it is utilized rapidly most has been removed from the water column. The proportion of $\mathrm{D}$ amino acids in seawater may be raised (Lee \& Bada 1977) because L-isomers are preferentially utilized. What is important is the flux of the compounds through the ecosystem. At least in oligotrophic waters, even at very low rates of degradation, labile fractions of DON may constitute a significant source of nitrogen for phytoplankton (Jackson \& Williams 1985).

Another point is that phytoplankton are not the only organisms which use dissolved nitrogen. Bacteria, for a given mass, actually assimilate more nitrogen than do phytoplankton because their cellular N/C ratio is greater. As a result, bacteria alone are unlikely to regenerate much nitrogen (Goldman \& Caron 1985). Regeneration will occur when these bacteria are 
grazed by animals which have a lower $\mathrm{N} / \mathrm{C}$ ratio and excrete the excess nitrogen (Pomeroy 1980), mainly as ammonium (Goldman \& Caron 1985). In addition to the incorporation of DON, bacteria also use nitrate and ammonium provided that, as is normal, there is a supply of DOC (Laws et al. 1985). As much as $90 \%$ of extracellular dissolved organic carbon (EOC) released by phytoplankton (equivalent to up to $30 \%$ of primary production) may be used by bacteria (Wolter 1982) but, because much is subsequently respired, the importance of this process may be underestimated (Jensen 1983). Given the ratios of DOC:DON in the water column (10:1 - Jackson \& Williams 1985), DOC:DFAA in algal exudaie (>10:1 - Mague et al. 1980), and that $63 \%$ of DOC compared with $34 \%$ of DFAA may be removed by bacteria (Hagström et al. 1984), it may be concluded that bacteria must often use a greater proportion of dissolved inorganic nitrogen (DIN) than DON to achieve a high cellular $\mathrm{N} / \mathrm{C}$ ratio. This must be so even if 20 to $60 \%$ DOC is respired whilst only 10 to $20 \%$ of nitrogen is excreted after uptake by bacteria (Azam et al. 1983). Any argument against the use of DFAA (a major component of DON) by phytoplankton based on bacterial competition may apply equally to the use of regenerated ammonium (Laws et al. 1985).

Bacteria have been thought to be the major users of DFAA but, with the realization that nanophytoplankton (Joint et al. 1986) and picophytoplankton (Platt et al. 1983) are ecologically important, it is possible that the size fractions collected by nets and filters previously thought to contain only bacteria may have included a significant proportion of nano/picophytoplankton and that these algae are partly responsible for the use of DFAA (Li \& Dickie 1985).

\section{POSSIBLE NITROGEN SOURCES FOR GROWTH OF PHYTOPLANKTON}

In theory, any nitrogenous compound which passes the plasma membrane and enters a biochemical pathway could be considered to be a nitrogen source. However, the processes of entering the cell and of incorporation must proceed rapidly if they are to contribute significantly to growth. Mechanisms for the transport and assimilation of nitrogenous compounds by microalgae have been discussed in detail by Raven (1980), Syrett (1981) and Wheeler (1983). However, for a variety of reasons, which will be discussed later, the rates of uptake measured in field and laboratory experiments may not be indicative of the importance of a particular substrate.

The pathway for the assimilation of ammonium is also that used during the assimilation of nitrate, nitrite, urea and purines because the initial stages of the incorporation of these compounds leads to the intracellular production of ammonium. Thus nitrate and nitrite are reduced by nitrate and nitrite reductases, urea is decarboxylated by urease or UALase, and purines are also degraded via several intermediates to ammonium (Syrett 1981). Following these reactions the ammonium is then incorporated into amino acids using the products of $\mathrm{CO}_{2}$ fixation. As a result of these reactions, the incorporation of all of these nitrogenous compounds is likely to interact with the rate of photosynthesis.

When an amino acid is used as a nitrogen source for growth, it is likely to be incorporated directly into protein. Extensive metabolism must, however, occur if other essential nitrogen compounds, including other amino acids, are to be formed from it. Such metabolism will probably involve degradation of the amino acid to ammonium and its subsequent assimilation. The products of photosynthesis may be required for this procedure because the carbon skeletons of some amino acids may be synthesized only by this route. For example the incorporation of amino acids into protein in Cyclotella cryptica is twice as rapid in light than darkness (Liu \& Hellebust $1976 \mathrm{~b}$ ). The incorporation of lysine-C by Phaeodactylum tricornutum proceeds at twice the rate in light as in darkness, while the incorporation of arginine-C is unaffected (Flynn \& Syrett 1986b). The incorporation of amino- $\mathrm{N}$ by Platymonas subcordiformis involves deamination followed by subsequent incorporation of the ammonium by the usual pathways (Stephens \& North 1971). However, when a simultaneous assimilation of several nitrogen sources occurs, the incorporation of amino- $\mathrm{N}$ may be expected to differ from that of the other nitrogen sources. If a mixture of amino acids is being taken up, or if there is a concurrent assimilation of a non-amino nitrogen source resulting in the release of amino acids into the intracellular amino acid pool, the extent to which any one amino acid will be catabolized and its nitrogen used in the synthesis of other compounds will be reduced. Although it may be expected that those amino acids with a high $\mathrm{N} / \mathrm{C}$ ratio would be better nitrogen sources than the others, this will ultimately depend on the rate and extent of catabolism (Flynn \& Syrett 1985).

In addition to the supply of nitrogen, DON may also be a source of carbon. The significance of this would depend on the rate of uptake, the $\mathrm{N} / \mathrm{C}$ ratio of the compound, and on the concurrent rate of photosynthesis. The fate of the amino acid-C will also depend on the type of amino acid and of the proximity of the catabolic pathway to respiratory and other pathways. The incorporation of DON-C may be expected to be 
most significant in the absence of photosynthesis: in turbid waters (e.g. estuaries), and at night.

The temporal availability of nitrogen sources is another factor to consider. If the source is only available in pulses then the cell must accumulate it and use it when the water is depleted of nitrogen. Algae often take up ammonium in preference to other sources (McCarthy et al. 1977), and take it up and incorporate it at very high rates regardless of the $\mathrm{N}$-status of the cell (McCarthy \& Goldman 1979). The ability to do this has been suggested to be an adaptation enabling algae to take up pulses of ammonium released by zooplankton (Dortch et al, 1982). The uptake of urea may also be uncoupled from growth (Horrigan \& McCarthy 1982). Other nitrogenous compounds may accumulate in cells, for example, basic amino acids in Platymonas subcordiformis (Wheeler \& Stephens 1977) and guanine in Chlorella fusca (Pettersen \& Knutsen 1974). These compounds are metabolized and the nitrogen used for growth when cells subsequently are deprived of other nitrogen sources. The intracellular pools of amino acids may act as a nitrogen buffer under such circumstances, especially in large diatoms (Admiraal ct al. 1986).

The relative importance of these factors will be affected by environmental conditions and the ability of individual species to adapt to those conditions. However, there does not appear to be any intrinsic reason why microalgae should not be able to use the low molecular weight $\left(\mathrm{M}_{\mathrm{r}}\right)$ components of DON such as DFAA and purines. There are considerable intra and interspecific differences in the abilities of microalgae to use ammonium, nitrate, nitrite, urea and amino-N (Carpenter \& Guillard 1971, Morris 1974, Antia et al. 1977. McCarthy 1981). Such abilities may be important for the development of algal species successions (Butler et al. 1979, Bonin \& Maestrini 1981).

Having considered some theoretical aspects of the ability to assimilate different sources of nitrogen, the results of field experiments will now be discussed in relation to those of laboratory studies.

\section{RESULTS FOR FIELDWORK AND LABORATORY STUDIES}

\section{Nitrate and ammonium}

That nitrate is an important source of nitrogen for the growth of phytoplankton never seems to have been questioned. Certainly its disappearance from the water column correlates with an increase in algal biomass, but this does not mean that it is the sole, or indeed at some times of the year the most important, $N$-source. It may simply reflect a long period of regeneration (prin- cipally advection following turnover of the water column in autumn). In contrast, the regeneration time for ammonium is very short. Although it is the major excretory product of marine animals, the concentration of ammonium may rarely be high because it is rapidly removed from the water column by algae and bacteria. It has been shown that ammonium, like nitrate, when added to nitrate-depleted natural waters is taken up by phytoplankton. This response has also been shown in laboratory studies in which it has also been shown that usually ammonium is taken up in preference to nitrate (Syrett \& Morris 1963, Cresswell \& Syrett 1979). Although this preference for ammonium may not be surprising, given that nitrate must be reduced to ammonium before it can be incorporated, the control of nitrate uptake, thought to involve a product of ammonium assimilation, is still poorly understood (Syrett 1981, Blasco \& Conway 1982).

Simultaneous uptake of ammonium and nitrate has been reported (Bienfang 1975, Caperon \& Ziemann 1976), and from the results presented by McCarthy et al. (1975) would be most likely to occur in natural conditions when the concentration of ammonium fall to below 1 umolar. The effect of high nitrate levels may also over-ride the inhibitory effects of ammonium if the proportion of nitrate:ammonium exceeds about 5 (Carpenter \& Dunham 1985), so that even if ammonium is preferred, nitrate is still an important source of nitrogen (Glibert et al. 1982a). Despite these results, the significance of ammonium in the nutrition of phytoplankton has been thought to be less than that of nitrate simply because of the disparity between the concentrations measured in the sea. Yet in the equatorial Atlantic Ocean, where levels of ammonium are very low, ammonium and not nitrate is thought to be the major source of nitrogen for primary producers, especially for picophytoplankton (LeBouteiller 1986).

Laboratory studies are now being made of the rapid cycling of regenerated ammonium, using mixed cultures of zooplankton, bacteria and phytoplankton (Goldman et al. 1985). It remains to be seen if bacteria use a significant proportion of this regenerated ammonium, together with dissolved organic carbon (DOC), for their own growth. Studies off Hawaii indicate that 50 to $75 \%$ of regenerated ammonium may be used by bacteria which may compete with the phytoplankters for inorganic nutrients (Laws et al. 1975). Pelagic bacteria have also been reported to instantaneously remove DOC released by phytoplankton (Larsson \& Hagstrom 1979), and as such exudates may account for a significant proportion of carbon fixed in primary production, bacterial growth using regenerated ammonium and DOC may well be of importance in some areas. 


\section{Urea}

Urea has also been shown to be a good source of nitrogen for the growth of natural populations and cultures of phytoplankton (Carpenter et al. 1972, McCarthy 1972, Turley 1985), and a diel periodicity for its assimilation has been noted (McCarthy \& Eppley 1972, Ignatiades 1986). The ability to use it as a Nsource has been suggested to be one of the factors affecting the succession of phytoplankton species (Remsen et al. 1974). Like nitrate, the uptake of urea by laboratory cultures may be inhibited by the presence of ammonium, although the inhibition of urea uptake may require a greater difference between the concentrations of the 2 substrates (McCarthy \& Eppley 1972 , Molloy pers. comm.). Urea uptake by phytoplankton in the Carmans River estuary is not affected by the presence of ammonium (Carpenter \& Dunham 1985), but in the Chesapeake Bay the order of nitrogen-source preference estimated over the course of the year was ammonium $>$ urea $>$ nitrate $>$ nitrite (McCarthy et al. 1977).

\section{Other components of DON}

The composition of a large proportion of DON is still under examination, but much of the unknown fraction (peptides, polypeptides and proteins) may be of no direct use to phytoplankton (except holozoic species) primaritiy because of the probiems of transport across the plasma membrane.

Another low molecular weight $\left(\mathrm{M}_{\mathrm{r}}\right)$ group of compounds are the purines and pyrimidines. These must be present in marine waters but, because of technical difficulties, their concentrations are unknown. Purines, but not pyrimidines, with their high $\mathrm{N}$-content per molecule, have been shown to be good sources of nitrogen for phytoplankters (Antia et al. 1975, Antia et al. 1980, Shah \& Syrett 1982, 1984). Uptake systems for guanine and hypoxanthine have been shown to develop in response to $\mathrm{N}$-deprivation in a similar fashion to those for other $\mathrm{N}$-sources (Shah \& Syrett 1982, 1984), but in contrast to the amino acid uptake systems, they do not appear to develop in response to C-deprivation (darkness). Uptake of guanine by Phaeodactylum tricornutum and by Amphora coffaeiformis, but not by Tetraselmis subcordiformis nor Dunaliella primolecta, is also inhibited by $1 \mathrm{mM}$ ammonium, although it is possible that more natural levels of ammonium would not be inhibitory (Shah \& Syrett 1984). Pettersen (1975) reported that levels of ammonium were involved in the regulation of guanine metabolism in Chlorella fusca which accumulates the purine until $\mathrm{N}$-deprived. These results suggest that the interaction of purine uptake with that of other $\mathrm{N}$ sources will need to be studied before any firm conclusions can be drawn about the role of these compounds. Because of the aforementioned technical difficulties, no field experiments have been conducted with these potential $\mathrm{N}$-sources.

\section{DFAA}

Attempts to measure the uptake of amino acids by natural algal populations have failed to show any significant levels of uptake by microalgae. The work of Schell (1974) suggests that off Southeast Alaska only 1 to $5 \%$ of diatom $\mathrm{N}$-requirements may be provided by amino-N (but see 'Contribution of amino-N', p. 297). From other studies it has been concluded that amino acids are utilized by bacteria (Williams 1970, Crawford et al. 1974, Iturriaga \& Zsolnay 1981, Ferguson \& Sunda 1984), rather than by algae, and that the bacterial incorporation of amino acids leads to a regeneration of ammonium which is used subsequently by the phytoplankton (Williams 1970, Hollibaugh 1976). However, it is possible that bacterial utilization of DFAA has been overestimated because of the addition of unnatural concentrations of test amino acids in field experiments. Bacteria may preferentially take up peptides (a component of DON) rather than DFAA; low concentrations of dipeptides $(10 \mathrm{nM})$ effectively halt amino acid uptake by non-competitive inhibition (Kurchman \& Hodson 1984), but such inhibition would be negated by the presence of high levels of amino acids. As a result, test amino acids may be removed rapidly by bacteria before a significant uptake by phytoplankton has occurred. Bacteria also seem to respond rapidly and positively to increased levels of DFAA by an increased rate of uptake (Williams \& Gray 1970 , Kirchman \& Hodson 1986). A similar problem is encountered in measuring uptake of ${ }^{15} \mathrm{~N}$-DIN by phytoplankton, as the unnaturally high substrate concentrations used may result in exaggerated rates of uptake (LeBouteiller 1986), and coincidently in a reduced ability to take up amino acids by transinhibition of uptake (see 'Transinhibition', p. 292).

The importance of DFAA for bacterial nutrition depends on the particle load (turbidity) of the water column, as attached bacteria use a greater proportion of amino acids in comparison with glucose than those which are free-living (Bell \& Albright 1982). The majority of marine bacteria are free-living (Azam et al. 1983), but the proportion which are attached increase in senescent phytoplankton populations (Albright et al. 1986). It has been suggested that the diversity of marine bacteria may give rise to the apparent consistency of the composition of DFAA (Sepers 1981), an 
idea supported by the work of Amano et al. (1982) and by the result given in Table $1 \mathrm{~g}$. However, it is possible that the apparent constant composition of DFAA may be as a consequence of methods of preparation in which samples are desalted and concentrated before analysis (Dawson \& Gocke 1978).

An additional problem is the apparent lack of correlation between the concentration of amino acids and primary production (Riley \& Segar 1970, Williams 1975, Jørgensen 1982). However, it is interesting to note that the measurements of DFAA by HPLC (Braven et al. 1984) over 1 yr at Station E1 (Fig. 2a) do suggest a correlation in that there is an obvious decline from March to June which follows that of nitrate. The work of Laanbroek et al. (1985) also suggests that levels of DFAA decrease during the spring bloom of the haptophycean Phaeocystis pouchetii, increasing at the end because of the activity of predators or because of cell lysis at senescence. The composition of DFAA also varied during the bloom. Poulet \& Martin-Jézéquel (1983) suggest that the release of DFAA by algae at the transition between periods of exponential and stationary growth (Admiraal et al. 1986) may attract zooplankton to the high standing stock which is then present.

\section{Conclusions}

From field observations it has been concluded that, of the potential sources of nitrogen which may be considered on theoretical grounds as being suitable for algal growth, nitrate, ammonium and urea alone are actually used. Data from the Carmans River estuary (dominant species were the diatoms Cylindrotheca closterium and Thalassiosira pseudonana in late spring and autumn, and the dinoflagellate Gyrodinium aureolum in July) give average rates of utilization, over $10 \mathrm{mo}$, of $45 \%$ nitrate, $43 \%$ ammonium and $12 \%$ urea (Carpenter \& Dunham 1985). The evidence is that amino- $\mathrm{N}$ is not incorporated directly by phytoplankton, and that it may be considered to be refractory (McCarthy et al. 1975). It is interesting to note that whilst bacteria are usually thought to use DFAA, urea (which is also a component of DON) is considered to be used by algae. From the results of filter-fractionation experiments, Remsen et al. (1972) concluded that algae, not bacteria, used most urea.

It is notable that the majority of the studies indicating that microalgae do not use DFAA were made before 1980. Since then improved detection methods for amino acids have become available and, as will be seen, recent laboratory experiments also cast doubts on some of the methods and conclusions of past studies.

\section{DEVELOPMENTS IN THE STUDY OF THE ROLE OF AMINO-N IN PHYTOPLANKTON NUTRITION}

In any discussion of laboratory experiments in which the utilization of organic nutrients by phytoplankton has been studied, it is important to bear in mind that the majority of the organisms used in such work were originally isolated in media containing nitrate as the sole $\mathrm{N}$-source. As a consequence, any species or subspecies which use DON extensively may have been selected against leaving us with a biased collection of organisms with which to work (Antia et al. 1975). It may be significant that few of the organisms available in axenic culture are representatives of species present in summer; most are either unrepresentative of the phytoplankton as a whole (having been isolated from rock pools or water butts) or are typical spring-bloom species normally found in high-nitrate waters. This isolation of algae in nitrate-medium contrasts with methods typically used for the isolation of marine bacteria which frequently involve the use of medium containing peptone and yeast extract. Not only may our algal cultures be dominated by species grown on nitrate, but the bacterial cultures may be dominated by species which grow best on DON.

\section{Growth experiments}

The vast majority of cultured algae can grow well using some component of DFAA (Provasoli \& McLaughlin 1963, Liu \& Hellebust 1974b, Wheeler et al. 1974, Antia et al. 1975, Hellebust \& Lewin 1977 , Fisher \& Cowdell 1982), although some species need a period of incubation (Berland et al. 1979) during which, presumably, transport and assimilatory systems develop. Large increases in the concentration of DFAA (by 10 to 100 -fold) have been shown to be accomodated within a period of 1 to $2 \mathrm{~d}$ (Williams \& Gray 1970) so algae can compete with bacteria for amino- $N$ only if they develop the ability to take up amino acids rapidly. How important periods of pre-incubation are to the uptake of DFAA by algae is difficult to say, but if the appropriate amino acids are always present, albeit at very much lower concentrations, the algae may already be adapted to make use of the pulses of amino acids excreted by zooplankton (Gardener \& Paffenhöer 1982).

An ability to grow rapidly utilizing amino- $\mathrm{N}$ is common especially in estuarine and near-shore species which would be expected to encounter higher concentrations of amino acids in the natural environment, thus pennate diatoms grow more rapidly than centric species using amino-N (Wheeler et al. 1974). Clones of diatoms from eutrophic and oligotrophic waters, in 
which $80 \%$ of total nitrogen is DON, have also been shown to be capable of utilizing fractions of DON, including DFAA (Fisher \& Cowdell 1982). By comparison, growth using the amino-sugar glucosamine is poor except at high (unnatural) concentrations (Berland et al. 1976).

For a few species, growth using amino-N actually exceeds that on nitrate or ammonium (Provasoli et al. 1957, Guillard 1963, Thomas 1966, Antia et al. 1975 , Landymore \& Antia 1977). In one set of experiments, 8 out of 26 species tested grew better using glycine rather than ammonium (Antia et al. 1975). Glycine is also reported to be a better source of nitrogen than inorganic nitrogen for Hemiselmis (Provasoli et al. 1957) and Nannochloris (Thomas 1966). It is, however, notable that the ability to use amino acids is highly variable between groups, species and even isolates of the same species (Cain 1965, Wheeler et al. 1974, Antia et al. 1975, Turner 1979, Neilson \& Larsson 1980). For example, Skeletonema costatum isolated from Dokai Bay, Japan, grew as rapidly on arginine as on nitrate, yet the same species isolated from Suho Nada could not grow on arginine at all (Yamada et al. 1983). This presumably reflects, in part, a difference in the relative importance of various biochemical pathways as much as the ability to take up the substrate (as described earlier).

Heterotrophic growth using amino acids has also been studied. Various species of the diatom Nitzschia can only grow in darkness on glucose in the presence of tryptone (Lewin 1963). Subsequent work revealed that glutamate can be used in place of tryptone, being used both as a source of nitrogen and of carbon (Lewin \& Lewin 1960, 1967, Hellebust \& Lewin 1977, Lewin \& Hellebust 1978). Tryptone or casamino acids, in conjunction with a carbohydrate source, will also support heterotrophic growth of Cylindrotheca fusiformis (Lewin \& Hellebust 1970), Cyclotella spp. (Lewin 1963), Navicula pavillardi (Lewin \& Hellebust 1975), and others (Sloan \& Strickland 1966). At least some cyanobacteria can grow heterotrophically with casamino acids as N-source (Hoare et al. 1971, White \& Shilo 1975).

The ability of algae to use the D-isomers of amino acids has not been studied widely. The marine diatoms Navicula incerta (Landymore \& Antia 1977) and Phaeodyctylum tricornutum (Hayward 1965) can grow on D-phenylalanine, but only at reduced rates. The type of experiment conducted by Lu \& Stephens (1984) and Ming \& Stephens (1985), in which cultured axenic algae are resuspended in seawater, should indicate whether algae can take up naturally occurring isomers of DFAA. If an amino acid is removed completely then it may be concluded that either the alga can take up both $\mathrm{L}$ and $\mathrm{D}$ isomers, or that $\mathrm{L}$-isomers predominate.
The uptake of L-phenylalanine by Chlorella fusca is not inhibited by the presence of the D-isomer (Pedersen \& Knutsen 1974), suggesting that the porter is stereospecific. However, it is possible that D-isomers are transported by algal amino acid porters but not used. If transinhibition (p. 292) by the D-isomers then occurred, the transport of L-isomers could be prevented. This possibility must be investigated.

The results from growth experiments have an important consequence for the design of field experiments. It is clearly not possible to supply only 1 or 2 amino acids (Schell 1974, Wheeler et al. 1977) and extrapolate from the resultant incorporation (or lack of it) by phytoplankton, as the test compounds may not be suitable substrates for the species present. This then presents the problem of selecting suitable amino acids for study. Does one use the most abundant amino acid already present in the water column, or that present at the lowest concentration? It rather depends on whether the amino acid present at the lowest level is at that low concentration because it is being rapidly removed from the environment, or because the rate of release is low. Ideally a mixture of all of the amino acids normally present in the water (as ${ }^{15} \mathrm{~N}$ and/or ${ }^{14} \mathrm{C}$ forms) should be added and their utilization followed by a subsequent analysis using HPLC to separate the compounds. Some form of substrate identification would have to be performed at a general level in order to ascertain which organisms were incorporating most ${ }^{15} \mathrm{~N}$ and ${ }^{14} \mathrm{C}$. This would be necessary because it is known that sometimes the $\mathrm{N}$-component is retained and the C-skeleton expelled by algae, and sometimes vice versa (Stephens \& North 1971, Schell 1974). The main problem with such experiments is the presence of bacteria which, if precautions are not taken, will adversely effect the reliability of the results (Fuhrman \& Bell 1985). Similar problems may also be encountered in attempts to measure the utilization of regenerated ammonium by phytoplankton (Laws et al. 1985).

Few authors have suggested, from the results of laboratory and field experiments, that natural growth rates could be obtained by the use of single amino acids (North \& Stephens 1967, North 1975). However, such an ability is probably of little importance in reality because a situation in which one amino acid is the only form of dissolved nitrogen present would not exist in nature. What is of importance is the extent of amino$\mathrm{N}$ incorporation which occurs simultaneously with that of other $\mathrm{N}$-sources. Thus during growth of Phaeodactylum tricornutum in a light/dark cycle, ammonium and arginine are simultaneously assimilated, with the incorporation of amino- $\mathrm{N}$ contributing $30 \%$ of cell- $\mathrm{N}$ (Flynn \& Wright 1986). 


\section{Transinhibition}

Transinhibition is a common feature of amino acid uptake in yeasts (Jones \& Wild 1973, Morrison \& Lichstein 1976), and has also been reported in Chlorella vulgaris (Sauer et al. 1983) and Phaeodactylum tricornutum (Flynn \& Syrett 1985). Transinhibition is a process by which the substrate itself limits transport (Harrison \& Christensen 1973) preventing an accumulation beyond the immediate needs of the cell. If it is a common feature of algal amino acid uptake systems then it may have adverse effects on attempts to measure the uptake by natural populations. Because of transinhibition, a cell with a full amino acid pool, of say arginine, will only take up arginine from the environment at the rate at which it is being removed from the pool for protein synthesis, and then only if the pool is not replenished by newly synthesized arginine. In $P$. tricornutum, cells growing on ammonium only have a greater ability (by a factor of 5) to instantly take up arginine than cells grown on ammonium plus arginine (Flynn \& Wright 1986). Transinhibition may also explain how amino acid uptake by $N$-replete, but not N-deplete, Platymonas subcordiformis is inhibited by the presence of ammonium (North \& Stephens 1971. Wheeler 1977); the rapid synthesis of amino acids from ammonium may increase the size of the intracellular amino acid pool and, hence, transinhibition by it.

A decreased ability to take up an amino acid relative to other $\mathrm{N}$-sources (especially ammonium) which may be taken up more rapidly than required for growth (McCarthy \& Goldman 1979), may indicate either that the amino acid is not taken up at a great rate (perhaps because the products of ammonium assimilation and photosynthesis are already satisfying the requirement), or that it has already been taken up and that, because of transinhibition, further transport is at a low rate (see Flynn \& Wright 1986). One possible reason for the low uptake rates of glycine and glutamate measured by Schell (1974) is that these amino acids are some of the first to be derived from photosynthetic incorporation of ammonium or nitrate (Beardall et al. 1976). When the cells are in the light in the presence of another N-source, the pool of these amino acids within the cell may be at a maximum resulting in transinhibition of transport.

If we are to examine the possibility of amino acid uptake by microalgae then it is essential that experiments are conducted under natural (in situ) conditions of light, at various times of the day, and using the full range of amino acids. The use of deck incubators with unrealistic illumination for the sampling depth should clearly be avoided. Any conditions likely to result in a filling of the intracellular amino acid pool, such as the addition of high levels of nitrate or ammonium, may also inhibit an uptake of amino acids.

\section{Effect of nitrogen deprivation}

When cultured phytoplankton are deprived of nitrogen (by incubation in $\mathrm{N}$-free medium in conditions in which they can photosynthesize), uptake systems for various nitrogenous compounds are often developed (e.g. Syrett et al. 1986). This is true of amino acid uptake systems (North \& Stephens 1971, 1972, Wheeler et al. 1974, Flynn \& Syrett 1985), but the rapidity and extent of development may be considerably less than for other $\mathrm{N}$-sources (Syrett et al. 1986). There is a noticeable lag before the development of the cationic amino acid uptake systems in Phaeodactylum tricornutum during which time other, non-amino, uptake systems develop rapidly (Flynn \& Syrett 1985, Syrett et al. 1986). This is consistent with the view that the regulation of amino acid uptake differs from that for other systems. If the control of the development and operation of the uptake systems is related to the size of the intracellular amino acid pool, as in yeast (Grenson et al. 1968, Bussey \& Umbarger 1970), then it may be expected that the effects of $\mathrm{N}$-deprivation would not be immediate. Transamination reactions should ensure, at least temporarily, a supply of all amino acids. This process may, however, only apply to cells which are photosynthesizing, as the products of photosynthesis are required for the synthesis of some amino acids (Hipkin et al. 1982).

Although a clear link between the size of the intracellular amino acid pool and the development and control of amino acid uptake systems in algae has not been proved, it is known that the pool does contract on $\mathrm{N}$-deprivation in Skeletonema costatum (Dortch 1982) and in other diatoms (Admiraal et al. 1986). In Phaeodactylum tricornutum there is a correlation between the state of development and extent of uptake which would be best explained by the involvement of the pool (Flynn \& Syrett 1985). Studies in which the intracellular concentrations of individual free amino acids are determined, with concurrent measurements of the development of amino acid uptake systems, are needed in order to test the idea further. Feedback from the total cellular amino acid pool has been suggested to regulate nitrate uptake in Skeletonema costatum (Conway 1977). Dortch et al. (1985) suggest that, amongst other indices, the intracellular amino acid/ protein ratio could be used to indicate the nitrogen status of natural algal populations. The work of Admiraal et al. (1986) suggests that, at least for diatoms, such an indicator may be of some use. Species like Platymonas subcordiformis accumulate some amino acids which are used when the cell is deprived of other nitrogen sources (Wheeler \& Stephens 1977). The uptake system for these amino acids presumably develops only after a protracted period of $\mathrm{N}$-depriva- 
tion, resulting in a reduction in the size of the intracellular amino acid pool to a critical level. The uptake rate of glycine by Platymonas subcordiformis is inversely related to the cellular nitrogen content; rates of uptake by $\mathrm{N}$-deplete cells are 10 times greater than by $N$-replete cells (North \& Stephens 1971).

Examination of the amino acid cycling by coastal diatoms, by Admiraal et al. (1984), showed that $\mathrm{N}$ deprived Amphiprora paludosa, Navicula salinarium and Nitzschia closterium can all take up L-amino acids. When $\mathrm{N}$-replete, and in the presence of nitrate, only $N$. closterium failed to take up any amino acids No substantial excretion of amino acids by $\mathrm{N}$-replete cells was detected except from Si-depleted $A$. paludosa. The conclusion drawn by the authors was that these diatoms would be net consumers of DFAA.

\section{Efifect of darkness}

In contrast with the development of uptake systems for other nitrogenous compounds, amino acid uptake systems also develop in response to carbon-deprivation (Lewin \& Hellebust 1975, 1976, Kirk \& Kirk 1978, Richards \& Thurston 1980, Flynn \& Syrett 1985, Flynn $\&$ Wright 1986). Schell (1974) reported that the uptake of amino acids by natural diatom populations off Alaska is twice as high in darkness as in light. Cdeprivation may occur either during a period of enforced darkness, or during the dark phase of a light/ dark cycle (simulating night) (Kirk \& Kirk 1978, Flynn \& Syrett 1985). Again the difference in operation of the amino acid uptake systems and those for other $N$ sources may be explained by the involvement of the intracellular amino acid pool in the regulation of amino acid uptake. Thus development of uptake systems in response to $\mathrm{N}$-deprivation and $\mathrm{C}$-deprivation may be controlled by the same regulatory mechanism. In Phaeodactylum tricornutum these stimuli are additive; cells deprived of nitrogen in darkness develop a cation amino acid uptake system quickest (Flynn \& Syrett 1985). In darkness, and therefore in the absence of photosynthetically produced C-skeletons, the synthesis of some amino acids may be restricted (Hipkin et al. 1982), leading to a reduction in the size of amino acid pool content. In $P$. tricornutum, the rate of development of the cationic amino acid uptake system is inversely proportional to the concurrent rate of photosynthesis in N-replete cells (Flynn \& Syrett 1985). This is consistent with the involvement of photosynthesis in amino acid synthesis, as reported for Chlorella pyrenoidosa (Smith et al. 1961).

Alternatively, development of amino acid uptake systems in darkness may be interpreted as a response to general $\mathrm{C}$-deprivation, with the cells responding in such a way that they become able to take up organic-C sources including amino acids. This interpretation has been considered to be unlikely as the products of amino acid degradation, when applied exogenously, do not enter respiratory pathways (Neilson \& Lewin 1974). However, there certainly is some respiration of amino acid-C by Phaeodactylum tricornutum and this is increased in conditions of darkness (Flynn \& Wright 1986).

The development of uptake systems for amino acids in darkness may have more importance in the natural environment than development in response to $\mathrm{N}$ deprivation. There is a cyclic development of an arginine uptake system in Chlamydomonas reinhardii, during which the amino acid uptake system develops during the dark phase and a urea uptake system develops during the light phase (Kirk \& Kirk 1978a). Phaeodactylum tricornutum develops an ability to take up lysine and arginine during the dark phase of growth on nitrate or ammonium, and would therefore presumably always have an ability to take up these amino acids (Flynn \& Wright 1986). Mopper \& Lindroth (1982) have shown that DFAA concentrations are at a maximum in the evening and a minimum at dawn in the Baltic Sea. This observation could in part be explained by the activity of phytoplankters which develop an ability to take up amino acids during the night. Levels of DFAA in daytime in the Celtic Sea are best explained by activity of zooplankton, whilst the much lower levels at night may reflect microbial utilization (Williams \& Poulet 1986). It would appear to be more appropriate to conduct field experiments to measure the uptake of DFAA by phytoplankton at night, or at dawn, rather than during the day when the products of photosynthesis together with the uptake of nitrate, ammonium or urea could restrict the uptake of DFAA by increasing the size of the intracellular amino acid pool.

Estuaries provide conditions where the development and operation of amino acid uptake systems might be expected to occur. DFAA concentrations are generally far higher in estuarine waters than in the open sea, and these levels can be increased during sediment turnover by tidal movements: the concentration of DFAA in sediment pore water can be several orders of magnitude greater than that of the overlying water column (Henrichs \& Farrington 1979, Jørgensen et al. 1980). The resultant high turbidity may also limit light penetration to less than $1 \mathrm{~m}$. Thus the phytoplankton of estuaries are subjected to periods of enforced darkness, superimposed on the normal diurnal cycle of day and night, in an environment potentially rich in amino acids. However, because such environments are also rich in other nutrients, amino acids may be used only if, as in Phaeodactylum tricornutum (Flynn \& Syrett 
1986a, Flynn \& Wright 1986), the uptake of amino acids is not inhibited by the presence of a large excess of ammonium or nitrate.

\section{Effect of salinity}

Salinity also has an effect on the uptake of amino acids. Rates of amino acid uptake and protein synthesis in Cyclotella cryptica are lowered in cells subjected to raised salinities (Liu \& Hellebust 1976a). Under such conditions proline is synthesised as a temporary osmoticum. The transport of amino acids into the cell may then be slower in response to a lower rate of removal of amino acids from the intracellular amino acid pool for protein synthesis. In Melosira nummuloides the transport system for amino acids operates with a higher affinity during periods of reduced salinity (McLean et al. 1981, Table 2). High rates of uptake and an apparent increase in substrate affinity developing in response to reduced salinity are possibly related (see 'Affinity of transport systems' p. 296).

There is clearly a need for experiments in which some of the basic conditions found in estuaries are simulated in the laboratory. The interactions of darkness, high substrate concentrations of ammonium and nitrate, and the effects of salinity on the operation of algal amino acid uptake systems needs to be examined. The effects of other combinations of conditions, such as those present at thermoclines and haloclines, which affect cells held below the euphotic zone also need to be examined.

\section{Operation of algal amino acid porters}

The mechanisms of amino acid transport across the plasma membrane in algae are described by Raven (1980) and Eddy (1982). Essentially it appears that amino acids are cotransported as a complex with $\mathrm{Na}^{+}$ (or $\mathrm{H}^{+}$for freshwater species) by electrogenic symport, with a concurrent efflux of $\mathrm{K}^{+}$(Raven 1980, Flynn \& Syrett 1986a).

As further evidence that amino acids should not be considered as a single $\mathrm{N}$-source, those algal amino acid porters studied are specific to groups of substrates (Hellebust 1970, Kirk \& Kirk 1978b; Table 2). Generally, transport of one amino acid is only inhibited by another amino acid of a similar ionic species, although presumably the extent of uptake could also be affected by the products of the transport and assimilation of another via transinhibition. As a consequence of the operation of transport systems specific to groups of amino acids, transport can occur of substrates which cannot support growth when supplied as the sole $\mathrm{N}$ source. Thus the freshwater alga Volvox carteri can take up arginine, but not grow on it (Kirk \& Kirk 1978). Nonetheless, the uptake of such amino acids, provided that they are a normal component of the cell, will supply the alga with a supplementary source of nitrogen and thus possibly decrease the requirement for other sources such as nitrate or ammonium.

As a result of the presence of these different porters, a simultaneous uptake of several amino acids (probably at least one per porter: 3 or 4 amino acids) could occur. The evidence from the few experiments in which a wide range of amino acids have been supplied together (Lu \& Stephens 1984, Ming \& Stephens 1985) suggests that a simultaneous uptake does occur, although Admiraal et al. (1986) suggest that uptake of some amino acids may be phased with growth. Such results must surely cast into doubt the conclusions of studies in which only one amino acid has been supplied. The uptake of one amino acid may indeed only contribute a few percent to the total N-budget, but the simultaneous uptake of half a dozen amino acids may be highly significant. Future experiments should make use of HPLC to measure the uptake of a wide range of amino acids from natural substrate concentrations.

Ammonium often inhibits the uptake of other Nsources (Eppley et al. 1969, Conway et al. 1976, Cresswell \& Syrett 1979, Shah \& Syrett 1984). Inhibition of amino acid uptake by other $\mathrm{N}$-sources is frequently either absent or only partial. In Phaeodactylum tricornutum ammonium has no effect on the uptake of arginine. On the contrary, ammonium assimilation is inhibited by $30 \%$ when arginine is present. Inhibition of ammonium uptake is particularly obvious during the dark phase of growth in a light/dark cycle (Flynn \& Wright 1986). Amino acids can also inhibit uptake of nitrite (Bilbao et al. 1981) and of urea (Kirk \& Kirk 1978). Uptake of amino acids by N-replete Platymonas subcordiformis is inhibited by the presence of ammonium (Wheeler 1977), but is not inhibited when cells are N-deplete (North \& Stephens 1971).

It is appropriate at this point to consider the process of amino acid loss from algae. Whilst it is known that one source of DFAA is phytoplankton exudate, little study has been made of the underlying processes. There appears to be 2 situations in which efflux could occur. One is by leakage from senescent or damaged cells and the other, from apparently healthy cells, seems to either be in response to osmotic shock (Liu \& Hellebust 1976a) or to changes in rates of ammonium assimilation, amino acid synthesis and protein synthesis which result in an 'overfilling' of the intracellular amino acid pool. The macrophyte Ulva appears to leak amino acids when subjected to abrupt changes in illumination (Jørgensen et al. 1980), while the release 
storage of samples in darkness before filtration) have been blamed (Sharp 1977, Fogg 1977, Mague et al. 1980). Similar problems may afflict studies of amino acid uptake. Inadequate washing of filtered cells leads to exaggerated uptake measurements, whilst filtration onto certain types of filter and under anything other than very low vacuum can result in cell rupture, leading to an underestimate of uptake (Fuhrman \& Bell 1985). The release of DFAA by healthy cells of exponentially growing Thalassiosira rotula measured by Hammer \& Eberlein (1981) may have been overestimated due to the use of glass-fibre filters which should not be used in such experiments (Fuhrman \& Bell 1985). Diatoms, especially large species, have now been shown to accumulate sizeable pools of free amino acids (Admiraal et al. 1986) and there must be an element of risk that such cells may rupture during filtration, liberating amino acids and creating the impression of DFAA excretion. However, there is little doubt that there are significant changes in the quantity and quality of DFAA present in the water column which occur during the course of diatom blooms (Brockmann et al. 1979, Hammer \& Kattner 1986). The problem is to discover which organisms are responsible for the release or uptake of which amino acids during these blooms.

Analysis of exudate using HPLC would be useful in investigating conditions leading to increased loss of amino acids, but radio-labelled amino acids would need to be used if a study of simultaneous influx and efflux of various amino acids was to be undertaken.

\section{Affinity of algal amino acid transport systems}

Another reason for the reluctance to accept a role for amino- $\mathrm{N}$ in the nutrition of phytoplankton is the apparent lack of substrate affinity (high $K_{s}$ values) measured for algal amino acid transport systems (Paul 1983). Values of $K_{s}$ quoted in the literature are often 1 to 2 orders of magnitude greater than the concentration of the substrates in natural waters (Table 2). The reason for this may be that amino acids are not significant N-sources for these (nitrate?) isolated species, or that the low levels of DFAA which we measure reflect uptake rather than release. An alternative reason may be that unless the cells are deprived of nitrogen and carbon in order to reduce the size of the intracellular amino acid pool to a minimum, and hence remove any effects of transinhibition, initial rates of transport are not being measured and post-transport assimilatory processes are affecting the result. This reasoning may explain why the lysine transport system in Phaeodactylum tricornutum apparently has a greater affinity after prolonged nitrogen and carbon deprivation than in $\mathrm{N}$ - replete cells (Flynn \& Syrett 1986a). Curiously some algae have 2 transport systems for amino acids. One is a high affinity system with a low $V_{\max }$ and the other a low affinity, high $V_{\max }$ system. The $K_{s}$ values for both systems are higher than natural substrate concentrations measured in the sea (Table 2). It would be most interesting to conduct the type of experiments described by Lu \& Stephens (1984) and Ming \& Stephens (1985), in which cultured phytoplankton are resuspended in seawater and their ability to remove naturally occurring DFAA measured, in order to test if the species with high apparent $K_{s}$ values for amino acid transport can actually take up amino acids from very low concentrations at significant rates.

It should be noted that whilst bacteria are widely considered to out-compete algae for DFAA, there are few experiments in which substrate competition has been studied. Saks \& Kahn (1979) demonstrated the successful competition by the diatom Cylindrotheca closterium for organic substrates against the bacterium Aeromonas.

\section{Incorporation of amino acid-carbon}

In addition to any effects that the incorporation of amino- $N$ may have on the growth of marine phytoplankton, assimilation of amino acid-C should be considered. It is known, from laboratory and field experiments, that the fate of amino acid- $\mathrm{C}$ varies depending on the particular substrate, the species of phytoplankton, and concurrent rates of photosynthesis. The carbon may be expelled after deamination (Stephens \& North 1971), respired (White 1974, Hellebust \& Lewin 1977. Wheeler \& Stephens 1977), or incorporated (Flynn \& Syrett 1986b, Flynn \& Wright 1986). Cells of Phaeodactylum tricornutum grown on arginine, in comparison with those grown on ammonium, have a reduced pigment content and correspondingly lower rates of photosynthesis (by $25 \%$ : Wright unpubl. results). The presence of amino acids also appears to affect the chlorophyll content of Cyclotella cryptica (Admiraal et al. 1986). Ming \& Stephens (1985) report that the incorporation of amino acid- $C$ by Melosira mediocris may be significant.

Measurements of primary production, by ${ }^{14} \mathrm{CO}_{2}$ fixation, may be underestimated if amino acid-C incorporation is a common occurrence. The use of pigment concentration, in order to estimate biomass, may also be adversely affected. 


\section{Contribution of amino- $\mathrm{N}$ to algal $\mathrm{N}$-requirements: Is it measurable in field experiments?}

Consider a hypothetical field experiment in which the bulk of primary production is attributed to only one species, and that species derives $80 \%$ of nitrogen from ammonium and $20 \%$ from amino-N. Of the 20 or so amino acids available, this species uses only 5 , so before going any further one would have a $75 \%$ probablility of choosing an inappropriate substrate, and hence measuring no amino acid incorporation at all. From results with Phaeodactylum spp. we could assume that the uptake of amino acids would be likely to be most important at night (Flynn \& Syrett 1985, Flynn \& Wright 1986), while uptake of ammonium at night is decreased considerably (Eppley et al. 1971, Flynn \& Wright 1986). If one assumed that $80 \%$ of ammonium and $25 \%$ of amino- $\mathrm{N}$ incorporation occurred in daylight, then in a typical field experiment conducted during the day with only one amino acid, only $1.0 \%(1.4 \%$ of day time uptake $)$ of the $\mathrm{N}$-requirement would be attributed to amino- $\mathrm{N}$ if, as has been done in the past, one assumed that the uptake of one ${ }^{14} \mathrm{C}$-amino acid equals that of all natural amino acids. A night experiment would indicate $3.0 \%\{9.6 \%$ of night-time uptake) attributed to amino- $\mathrm{N}$. These will be average values as the probability that each of the 5 amino acids is incorporated at the same rate is low. Enlarge the populations to 3 species, which may or may not use the same amino acids, bear in mind low cell densities and low growth rates typical of natural populations, and the inadequacies of testing 1 or 2 amino acids become all too obvious. The detection of a significant uptake of any one amino acid, even using HPLC, may border on the limits of statistical significance. Yet surely $20 \%$ of total nitrogen requirement is a significant proportion.

One method of conducting field experiments would be to introduce a full range of radiolabelled amino acids and, after incubation, to separate them by HPLC. By comparing the ratio of labelled to unlabelled individual amino acids in the water before and after incubation, the net rate of uptake, or excretion, could be calculated. The inclusion of labelled substrates enables the detection of uptake in the presence of continued regeneration (isotope dilution technique). If samples were to be fractionated before the addition of the substrates, as recommended by Wheeler et al. (1977), then care must be taken not to shock the cells by changing conditions of light. This would be especially important when conducting experiments with cells from the lower euphotic zone or at night.

Clearly uptake rates of amino acids should not be compared directly with those of ammonium or urea, as initial rates of uptake of the latter may be uncoupled from growth (Horrigan \& McCarthy 1982). It is probably inappropriate to compare uptake rates at any one time of day and to calculate the overall contribution because of the effects of photosynthesis. Whilst the uptake of DIN, urea and guanine may be broadly coupled with photosynthesis, it appears that rates of amino acid uptake are likely to be inversely correlated with photosynthesis (Flynn \& Syrett 1985). Unfortunately, attempting to place previously photosynthesizing cells in darkness, or the other way around, may lead to shock-induced release of amino acids from the cells (Sharp 1977).

Any implications for the use of enhancement ratios for dark $\mathrm{CO}_{2}$ fixation to determine the $\mathrm{N}$-status of algae which are utilizing DON should also be considered; it is known that urea may not give any enhancement (Goldman \& Dennett 1986). This technique may only be applicable for algae utilizing DIN. Finally, Poulet et al. (1985) have warned against the use of measurements of phytoplankton biomass in field experiments, because a high proportion of algae may not be metabolically active thus reducing the apparent uptake of amino acids.

\section{ROLE OF DON IN THE NUTRITION OF NANO/ PICOPHYTOPLANKTON}

Studies of this size group of algae are in their infancy; it is only recently that their importance to marine primary production has been established (Platt et al. 1983, Joint et al. 1986). The principal users of DFAA were originally ascribed to the bacteria-size fraction (Williams 1970) but with the emergence of these small algae as an important component of the phytoplankton it is possible that a significant proportion of DFAA may be used by these organisms in addition to by bacteria.

Because of the paucity of axenic cultures, effectively no study has been made of the role of DON in the nutrition of nano/picophytoplankton, but as all other algae studied to date are capable of at least some growth using DON it would be most unusual if they could not do so. Li \& Dickie (1985) report the uptake of ${ }^{3} \mathrm{H}$-amino acids by picoplankters and, whilst illumination had little effect on Sargasso Sea populations, in Lancaster Sound uptake was greater in darkness. From the use of inhibitors, it was concluded that most of the amino acids were used by prokaryotes, of which a proportion were photosynthetic. Picophytoplankton inhabit the lower photic zone and, adapted as they may be to such levels of illumination (Glover et al. 1986), may be adapted to take up organic nutrients in the same way that other microalgae take up amino acids in response to darkness (Flynn \& Syrett 1985, Lewin \& 
Hellebust 1975, 1976). Certainly their large surface area/volume ratio would facilitate the rapid uptake of such compounds.

Much work must be performed on the N-nutrition of these algae before we know the answers, but clearly they have the potential for being significant users of DFAA. In a survey of primary production in the Celtic Sea (Joint et al. 1986), the peak of phytoplankton $(>5 \mu \mathrm{m})$ production was in April, of nanoplankton $(<5 \mu \mathrm{m}$ to $2 \mu \mathrm{m})$ was over the period from May to August, and of picoplankton $(<2 \mu \mathrm{m})$ in May and in August. Thus the nano/picophytoplankton blooms occur during summer when levels of nitrate are low. Do they use DFAA in addition to regenerated ammonium?

\section{CONCLUSIONS}

From the foregoing discussion on DFAA utilization by microalgae the following conclusions can be drawn.

(1) The composition of DFAA in seawater appears to reflect microbial use. Algal as well as bacterial utilization could be used to explain the composition.

(2) The ability of microalgae to take up individual amino acids and to grow using amino- $\mathrm{N}$ is highly variable both between and within species, and may well be a factor affecting species succession.

(3) The development and operation of microalgal amino acid uptake systems appears to be dissimilar to that of nitrate and ammonium, probably because control is at the level of the intracellular amino acid pool, as in yeasts. As a consequence, cells exposed to high levels of illumination in the presence of DIN are likely to take up amino acids at the lowest rate because the intracellular synthesis of amino acids transinhibit their transport from the exterior.

(4) N-deprivation and C-deprivation (darkness) result in a decrease in the size of the intracellular amino acid pool and stimulate the development of amino acid uptake systems.

(5) Microalgae can simultaneously take up several amino acids because they possess porters for groups of amino acids. Furthermore, because amino- $N$ need not enter the same biosynthetic pathways as other $\mathrm{N}$-sources, a simultaneous assimilation of several amino acids plus DIN can occur. The uptake rate of any one amino acid under such circumstances may be expected to be low although the total contribution of amino- $\mathrm{N}$ may be significant.

(6) Microalgae can take up amino acids from natural concentrations found in seawater.

(7) Release of DFAA by algae may be in response to shock or damage, and a net loss is only to be expected from cells growing under high levels of illumination in the presence of excess DIN (see [3]).
(8) Laboratory experiments should be conducted using cells grown in light/dark cycles, not in continuous light, with near-natural cell densities and nutrient concentrations. More axenic cultures of phytoplankton species typical of summer months are required and such species should be isolated in medium containing suitable sources of nitrogen and phosphorous for the environment from which they were removed.

(9) Field experiments must be conducted with great care to prevent shock-induced release of DFAA from algae, with natural levels of illumination (including studies at night), and with the full range of amino acids supplied at low concentrations. The possibility of bacterial interference must be considered.

In the light of these conclusions it is clear that there is scope for doubting the original contention that DFAA are not used by phytoplankton. With hindsight the design of past experiments, if not the interpretation of their results, can be seen to have been flawed in certain fundamental areas. Fresh attempts need to be made to solve the problem.

It is apparent that, irrespective of the question of DFAA utilization by phytoplankton, measurements of this important group of compounds should be made routinely (night and day) with those of other nitrogenous compounds. As new techniques become available, other components of DON should also be measured. There is an urgent need to estimate the flux of components of DFAA and to measure the composition of DFAA exudate from zooplankton, for at present we do not have data indicating the relative importance of individual amino acids in the N-cycle. Such information would be of great use in field and laboratory experiments, but until this becomes available the full range of amino acids should be used in experiments designed to examine the uptake of DFAA by phytoplankton. Fortunately, with the advent of new techniques this no longer presents the problems that it used to, although it would still be a complex undertaking.

The study of marine primary production was originally confined to that of the nitrate-dominated spring diatom bloom, whilst laboratory work centered on the physiology of diatoms and unrepresentative species including freshwater Chlorophyta (used as model green plants rather than model marine phytoplankton). Nitrate was shown to be a/the major source of nitrogen for these species. The danger is that, by assuming that nitrate is the most important source of nitrogen for the growth of phytoplankton throughout the year, we may have unwittingly only studied the physiological ecology of species typical of the nitrate-dominated spring bloom (mainly diatoms). As a consequence the ecology of the phytoplankton present in summer, when nitrate concentrations are at their lowest, remain something of an unknown quantity. Even the bloom-forming dino- 
flagellates have been poorly studied in the laboratory because only a few axenic cultures are available.

If the microalgal utilization of DFAA, and of other as yet unconsidered components of DON, were shown to be significant, either in terms of nitrogen or carbon input, it would have considerable repercussions on our conception of the ecology of phytoplankton.

Acknowledgement. We thank Professor P. J. Syrett for helpfui comments and discussion during the preparation of this review.

\section{LITERATURE CITED}

Admiraal, W., Laane, R. W. P. M., Peletier, H. (1984). Participation of diatoms in the amino acid cycle of coastal waters; uptake and excretion in cultures. Mar. Ecol. Prog. Ser. 15: 303-306

Admiraal, W., Peletier, H., Laane, R. W. P. M. (1986). Nitrogen metabolism of marine planktonic diatoms; excretion, assimilation and cellular pools of free amino acids in seven species with different cell size. J. exp. mar. Biol. Ecol. 98: 241-263

Albright, L. J., McCrea, S. K., May, B. E. (1986). Attached and free-floating bacterioplankton in Howe Sound, British Columbia, a coastal marine fjord-embayment. Appl. environ. Microbiol. 51: 614-621

Alexander, R. McN. (1975). The chordates. Cambridge University Press, Cambridge

Amano, M., Hara, S., Taga, N. (1982). Utilization of dissolved amino acids in sea water by marine bacteria. Mar. Biol. 68: $31-36$

Andersson, A., Lee, C., Azam, F., Hagström, A. (1985). Rolcase of amino acids and inorganic nutrients by heterotrophic marine microflagellates. Mar Ecol. Prog. Ser 23: 99-106

Antia, N. J., Berland, B. R., Bonin, D. J. (1980). Proposal for an abridged nitrogen turnover cycle in certain marine planktonic systems involving hypoxanthine-guanine excretion by ciliates and their reutilization by phytoplankton. Mar Ecol. Prog. Ser. 2: 97-103

Antia, N. J., Berland, B. R., Bonin, D. J., Maestrini, S. Y (1975). Comparative evaluation of certain organic and inorganic sources of nitrogen for phototrophic growth of marine microalgae. J. mar. biol. Ass. U.K. 55: 519-539

Antia, N. J., Berland, B. R., Bonin, D. J., Maestrini, S. Y (1977). Effects of urea concentration in supporting growth of certain marine microplanktonic algae. Phycologia 16: 105-111

Antia, N. J., Landymore, A. F. (1974). Physiological and ecological significance of the chemical instability of uric acid and related purines in sea water and marine algal culture medium. J. Fish. Res. Bd Can. 31: 1327-1335

Atkins, W. R. G. (1923). The phosphate content of fresh and salt water in its relation to the growth of algal plankton. Part 1. J. mar. biol. Ass. U.K., NS 13: 119-150

Azam, F., Fenchel, T., Field, J. G., Gray, J. S., Meyer-Reil, L. A., Thingstad, F. (1983). The ecological role of watercolumn microbes in the sea. Mar. Ecol. Prog. Ser. 10: 257-263

Beardall, J., Mukerji, D., Glover, H. E., Morris, 1. (1976). The path of carbon in photosynthesis by marine phytoplankton. J. Phycol. 12: 409-417

Bell, C. R., Albright, L. J. (1982). Attached and free-floating bacteria in a diverse selection of water bodies. Appl. environ. Microbiol. 43: 1227-1237

Berland, B. R., Bonin, D. J., Maestrini, S. Y., Lizarraga-Partida, M. L.., Antia, N. J. (1976). The nitrogen concentration requirement of $D$-glucosamine for supporting effective growth of marine microalgae. J. mar biol. Ass. U.K. 56: $629-637$

Berland, B. R., Bonin, D. J., Guerin-Ancey, O., Antia, N. J. (1979). Concentration requirement of glycine as nitrogen source for supporting effective growth of certain marine microplanktonic algae. Mar. Biol. 55: 83-92

Bidigare, R. R. (1983). Nitrogen excretion by marine zooplankton. In: Carpenter, E. J., Capone, D. G. (ed.). Nitrogen in the marine environment. Academic Press Inc, London, p. 385-410

Bienfang, P. K. (1975). Steady state analysis of nitrateammonium assimilation by phytoplankton. Limnol. Oceanogr. 20: 402-411

Bilbao, M. M., Gabas, J. M., Serra, J. L. (1981). Inhibition of nitrite uptake in the diatom Phaeodactylum tricornutum by nitrate, ammonium and some L-amino acids. Biochem. Soc. Trans. 9: $476-477$

Blasco, D., Conway, H. L. (1982). Effect of ammonium on the regulation of nitrate assimilation in natural phytoplankton populations. J. exp. mar Biol. Ecol. 61:157-168

Boalch, G. T., Harbour, D. S., Butler, E. I. (1978). Seasonal phytoplankton production in the Western English Channel 1964-1974. J. mar biol. Ass. U.K. 58: 943-953

Bonin, D. J., Maestrini, S. Y. (1981). Importance of organic nutrients for phytoplankton growth in the natural environment: Implications for algal species succesion. In: Platt, T. (ed.) Physiological bases of phytoplankton ecology. Can. Bull. Fish. Aquat. Sci. 210: 279-291

Braven, J., Evens, R., Butler, E. I. (1984). Amino acids in sea water Chem. Ecol 2: 11-21

Brockmann, U. H., Eberlein, K., Hosumbek, P., Trageser, H., Máer-Reiner, E., Schüne, II. K. Junge, I1. D. (1977). The development of a natural plankton population in an outdoor tank with nutrient-poor sea water I. Phytoplankton succession. Mar. Biol. 43: 1-18

Brockmann, U. H., Eberlein, K., Jange, H. D., Maier-Reimer, E., Siebers, D. (1979). The development of a natural plankton population in an outdoor tank with nutrient-poor sea water II. Changes in dissolved carbohydrates and amino acids. Mar Ecol. Prog. Ser 1: 283-291

Bussey, H., Umbarger, H. E. (1970). Biosynthesis of the branched-chain amino acids in yeast: A leucine-binding component and regulation of leucine uptake. J. bacteriol. 103: $277-285$

Butler, E. I., Knox, S., Liddicoat, M. I. (1979). The relationship between inorganic and organic nutrients in sea water. J. mar. biol. Ass. U.K. 59: 239-250

Cain, J. (1965). Nitrogen utilization in 38 freshwater Chlamydomonad algae. Can. J. Bot. 43: 1367-1378

Carlucci, A. F., Craver, D. B., Henrichs, S. M. (1984). Diel production and microheterotrophic utilization of dissolved free amino acids in waters off Southern California. Appl. environ. Microbiol. 48: 165-170

Carpenter, E. J. (1983). Nitrogen fixation in marine Oscillatoria (Trichodesmium) in the World's oceans. In: Carpenter, E. J., Capone, D. G. (ed.). Nitrogen in the marine environment. Academic Press Inc., London, p. 65-104

Carpenter, E. J., Capone, D. G. (ed.) (1983). Nitrogen in the marine environment. Academic Press Inc., London

Carpenter, E. J., Dunham, S. (1985). Nitrogenous nutrient uptake, primary production, and species composition of 
phytoplankton in the Carmans River estuary, Long Island, New York. Limnol. Oceanogr 30: 513-526

Carpenter, E. J. Guillard, R. R. L. (1971). Intraspecific differences in nitrate half-saturation constants for three species of marine phytoplankton. Ecology 52: 183-185

Carpenter, E. J., Remsen, C. C., Watson, S. W. (1972). Utilization of urea by some marine phytoplankters. I_imnol. Oceanogr. 17: 265-269

Caperon, J., Ziemann, D. A. (1976). Synergistic effects of nitrate and ammonium ions on the growth and uptake kinetics of Monochrysis lutheri in continuous culture. Mar. Biol. 36: 73-84

Cho, B.-H., Sauer, N., Komor, E., Tanner, W. (1981). Glucose induces two amino acid transport systems in Chlorella. Proc. natl Acad. Sci. USA 78: 3591-3594

Colwell, R. R., Liston, J. (1961). Taxonomic relationships among the pseudomonads. J. Bacteriol. 81. 1-14

Conway, H. L. (1977). Interaction of inorganic $N$ in the uptake and assimilation by marine phytoplankton. Mar. Biol. 39: $221-232$

Conway, H. L., Harrison, P. J., Davis, C. O. (1976), Marine diatoms grown in chemostats under silicate or ammonium limitation. II. Transient response of Skeletonema costatum to a single addition of the limiting nutrient. Mar. Biol. 35: 187-199

Corner, E. D. S., Newell, B. S. (1967). On the nutrition and metabolism of zooplankton. IV The forms of nitrogen excreted by Calanus. J. mar biol. Ass. U.K. 47: 113-120

Corner, E. D. S., Head, R. N., Kilvington, C. C. (1972). On the nutrition and metabolism of zooplankton. VIII. The grazing of Biddulphia cells by Calanus helgolandicus. J. mar biol. Ass. U.K. 52: 847-861

Comer, E. D. S., Head, R. N., Kilvington, C. C., Penneycuick, L. (1976). On the nutrition and metabolism of zooplankton. $X$. Quantitative aspects of Calanus helgolandicus feeding as a carnivore. J. mar. biol. Ass. U.K. 56: 345-358

Cowey, C. B., Corner, E. D. S. (1966). The amino-acid composition of certain unicellular algae, and of the faecal pellets produced by Calanus finmarchicus when feeding on them. In: Barnes, H. (ed.) Some contemporary studies in marine science. George Allen \& Unwin, London, p. 225-231

Crawford, C. C., Hobbie, J. E., Webb, K. L. (1974). The utilization of dissolved free amino acids by estuarine microorganisms. Ecology 55: 551-563

Cresswell, R. C., Syrett, P. J. (1979). Ammonium inhibition of nitrate uptake by the diatom Phaeodactylum tricornutum. Plant. Sci. Lett. 14: 321-325

Cushing, D. H. (1975). Marine ecology and fisheries. Cambridge University Press, Cambridge

Dagg, M. J., Vidal, J., Whitledge, I E., Iverson, R. L., Goering, J. J. (1982). The feeding, respiration, and excretion of zooplankton in the Bering Sea during a spring bloom. Deep Sea Res. 29: 45-63

Dawson, R., Gocke, K. (1978). Heterotrophic activity in comparison to the free amino acid concentrations in Baltic Sea water samples. Oceanologica Acta 1. 45-54

Dawson, R., Mopper, K. (1978). A note on the losses of monosaccharides, amino sugars, and amino acids from extracts during concentration procedures. Analyt. Biochem. 84: 186-190

Degobbis, D., Homme-Maslocoska, E., Orio, A. A., Donazzolo, R., Pavoni, B. (1986). The role of alkaline phosphatase in the sediments of Venice Lagoon on nutrient regeneration. Estuar. coast Shelf Sci. 22: 425-437

Dortch, Q. (1982). Effect of growth conditions on accumulation of internal nitrate, ammonium, amino acids, and pro- tein in three marine diatoms. J. exp. mar. Biol. Ecol. 61 243-264

Dortch, Q., Clayton Jr., J. R., Thoreson, S. S., Bressler, S. L. Ahmed, S. I. (1982). Response of marine phytoplankton to nitrogen deficiency: Decreased nitrate uptake vs enhanced ammonium uptake. Mar. Biol. 70: 13-19

Dortch, Q., Clayton Jr., J. R., Thoresen, S. S., Cleveland, J. S. Bressler, S. L., Ahmed, S. I. (1985). Nitrogen storage and use of biochemical indices to assess nitrogen deficiency and growth rate in natural plankton populations. J. mar Res. 43: 437-464

Eddy, A. A. (1982). Mechanisms of solute transport in selected eukaryotic micro-organisms. Adv. microb. Physiol. 23: $1-78$

Eppley, R. W., Rogers, J. N., McCarthy, J. J. (1969). Half saturation constants for uptake of nitrate and ammonium by marine phytoplankton. Limnol. Oceanogr. 14: 912-920

Eppley, R. W., Rogers, J. N., McCarthy, J. J. (1971). Light/dark periodicity in nitrogen assimilation of the marine phytoplankters Skeletonema costatum and Coccolithus huxleyi in N-limited chemostat culture. J. Phycol. 7: 150-154

Evens, R., Braven, J., Brown, L., Butler, I. (1982). A high performance liquid chromatographic determination of free amino acids in natural waters in the picomolar $(\mathrm{M} \times$ $10^{-12}$ ) range suitable for shipboard use. Chem. Ecol. 1 99-106

Ferguson, R. L., Sunda, W. G. (1984). Utilization of amino acids by planktonic marine bacteria: Importance of clean technique and low substrate concentrations. Limnol Oceanogr. 29: 258-274

Fisher, N. S., Cowdell, R. A. (1982). Growth of marine planktonic diatoms on inorganic and organic nitrogen. Mar Biol. 72 : $147-155$

Flynn, K. J., Syrett, P. J. (1985). Development of the ability to take up L-lysine by the diatom Phaeodactylum tricornutum. Mar. Biol. 89: 317-325

Flynn, K. J., Syrett, P. J. (1986a). Characteristics of the uptake system for L-lysine and L-arginine in Phaeodytylum tricornutum. Mar. Biol. 90: 151-158

Flynn, K. J., Syrett, P. J. (1986b). Utilization of L-lysine and Larginine by the diatom Phaeodactylum tricornutum. Mar. Biol. 90: 159-163

Flynn, K. J., Wright, C. R. N. (1986). The simultaneous assimilation of ammonium and L-arginine by the diatom Phaeodactylum tricornutum Bohlin. J. exp. mar. Biol. Ecol. 95: $257-269$

Fogg, G. E. (1966). The extracellular products of algae Oceanogr. mar. biol. A. Rev. 4: 195-212

Fogg., G. E. (1977). Excretion of organic matter by phytoplankton. Limnol. Oceanogr. 22: 576-577

Forster, R. P., Goldstein, L. (1969). Formation of excretory products. In: Hoar, W. S., Randall, D. J. (ed.) Fish physiology 1. Academic Press Inc., London, p. 313-350

Fuhrman, J. A., Bell, T M. (1985). Biological considerations in the measurement of dissolved free amino acids in sea water and implications for chemical and microbiological studies. Mar. Ecol. Prog. Ser. 25: 13-21

Gardener, W. S., Paffenhöfer, G. A. (1982). Nitrogen regeneration by the subtropical marine copepod Eucalanus pileatus. J. Plankton Res. 4: 725-734

Glibert, P. M. (1982). Regional studies of daily, seasonal and size fraction variability in ammonium remineralization. Mar Biol. 70: 209-222

Glibert, P. M., Goldman, J. C., Carpenter, E. J. (1982a). Seasonal variations in the utilization of ammonium and nitrate by phytoplankton in Vineyard Sound, Massachusetts, U.S.A. Mar. Biol. 70: 237-249 
Glibert, P. M., Lipschultz, F., McCarthy, J. J., Altabet, M. A. (1982b). Isotope dilution models of uptake and remineralization of ammonium by marine plankton. Limnol. Oceanogr. 27. 639-650

Glover, H. E., Keller, M. D., Guillard, r R. 1. (1986). Light quality and oceanic ultraphytoplankters. Nature, Lond. 319: $142-143$

Goldman, J. C., Caron, D. A. (1985). Experimental studies on an omnivorous microflagellate: Implications for grazing and nutrient regeneration in the marine microbial food chain. Deep Sea Res. 8: 899-915

Goldman, J. C., Caron, D. A., Anderson, O. K., Dennett, M. R. (1985). Nutrient cycling in a microflagellate food chain: I Nitrogen dynamics. Mar. Ecol. Prog. Ser. 24: 231-242

Goldman, J. C., Dennett, M. R. (1986). Dark $\mathrm{CO}_{2}$ uptake by the diatom Chaetoceros simplex in response to nitrogen pulsing. Mar. Biol. 90: 493-500

Goldman, J. C., McCarthy, J. J., Peavey, D. G. (1979). Growth rate influence on the chemical composition of phytoplankton in oceanic waters. Nature, Lond. 279: 210-215

Grenson, M., Crabeel, M., Wiame, J. M., Béchet, J. (1968). Inhibition of protein synthesis and stimulation of permease tumover in yeast. Biochem. biophys. Res. Commun. 30: $414-419$

Guillard, R. R, L. (1963). Organic sources of nitrogen for marine centric diatoms. In: Oppenhiemer, C. H. (ed.). Marine microbiology. Charles C. Thomas Publishing, Springfield, Illinois, p. 93-104

Hagström, A., Ammerman, J. A., Henrichs, S., Azam, F. (1984). Bacterioplankton growth in sea water. 2. Organic matter utilization during steady-state growth. Mar. Ecol Prog. Ser. 18: 41-48

Hammer, K. D., Brockmann, U. H. (1983). Rhythmic release of dissolved free amino acids from partly synchronized Thalassiosira rotula under nearly natural conditions. Mar Biol. 74: 305-312

Hammer, K. D., Eberlein, K. (1981). Parallel experiments with Thalassiosira rotula in outdoor plastic tanks: Development of dissolved free amino acids during an algae bloom. Mar. Chem. 10: 533-544

Hammer, K. D., Kattner, G. (1986). Dissolved free amino acids in the marine environment: a carbon to nitrogen ratio shift during diatom blooms. Mar Ecol. Prog. Ser. 31: 35-45

Harrison, L. I., Christensen, H. N. (1973). Analog-computer simulation of trans effects in facilitated diffusion. Fedn Proc. Fedn Am. Socs exp. Biol. 32: 234

Hayward, J. (1965). Studies on the growth of Phaeodactylum tricornutum (Bohlin). I. The effect of certain organic nitrogenous substances on growth. Physiologia Pl. 18: 201-207

Heath, R. T. (1986). Dissolved organic phosphorus compounds: Do they satisfy planktonic phosphate demand in summer? Can. J. Fish. Aquat. Sci. 43: 343-350

Hellebust, J. A. (1965). Excretion of some organic compounds by marine phytoplankton. Limnol. Oceanogr. 10: 192-206

Hellebust, J. A. (1970). The uptake and utilization of organic substances by marine phytoplankters. In: Hood, D. W. (ed.). Symposium on organic matter in natural waters. Inst. Mar. Sci. Occasional Publ. no. 1, University of Alaska, College, p. 225-256

Hellebust, J. A., Guillard, R. R. L. (1967). Uptake specificity for organic substrates by the diatom Melosira nummuloides. J. Phycol. 3: 132-136

Hellebust, J. A., Lewin, J. (1977). Heterotrophic nutrition. In: Werner, D. (ed.). The biology of diatoms. Bot. Monographs 13. Blackwell Scientific Pub., Oxford, p. 169-197

Henrichs, S. M., Farrington, J. W. (1979). Amino acids in interstitial waters of marine sediments. Nature Lond. 279 : 319-322

Hipkin, C. R., Everest, S. A., Rees, T. A. V., Syrett, P. J. (1982). Ammonium regeneration by nitrogen-starved cultures of Chlamydomonas reinhardii. Planta 154: 587-592

Hoare, D. S., Ingram, L. O., Thurston, E. L., Walkup, R. (1971). Dark heterotrophic growth of an endophytic blue-green alga. Arch. Mikrobiol. 78: 310-321

Hollibaugh, J. T. (1976). The biological degradation of arginine and glutamic acid in sea water in relation to the growth of phytoplankton. Mar. Biol. 36: 303-312

Hollibaugh, J. T., Azam, F. (1983). Microbial degradation of dissolved protein in seawater. Limnol. Oceanogr. 28: 1104-1106

Holligan, P. M., Balch, W. M., Yentsch, C. M. (1984). The significance of subsurface chlorophyll, nitrite and ammonium maxima in relation to nitrogen for phytoplankton growth in stratified waters of the Gulf of Maine. J. mar Res. 42: 1051-1073

Horrigan, S. G., McCarthy, J. J. (1982). Phytoplankton uptake of ammonium and urea during growth on oxidized forms of nitrogen. J. Plankton Res. 4: 379-390

Ignatiades, L. (1986). Annual variability of $\left({ }^{14} \mathrm{C}\right)$ urea utilization by natural marine phytoplankton. Br. phycol. J. 21: 209-215

Iturriaga, R., Zsolnay, A. (1981). Transformation of some dissolved organic compounds by a natural heterotrophic population. Mar. Biol. 62: 125-129

Jackson, G. A., Williams, P. M. (1985). Importance of dissolved organic nitrogen and phosphorus to biological nutrient cycling. Deep Sea Res. 32: 223-235

Jawed, M. (1969). Body nitrogen and nitrogenous excretion in Neomysis rayii Nurdoch and Euphausia pacifica Hansen. Limnol. Oceanogr. 14: 748-754

Jawed, M. (1973). Ammonia excretion by zooplankton and its significance to primary productivity during summer Mar Biol. 23: 115-120

Jensen, L. M. (1983). Phytoplankton release of extracellular organic carbon, molecular weight composition and bacterial assimilation. Mar. Ecol. Prog. Ser. 11: 39-48

Joint, I. R., Owens, N. J. P., Pomeroy, A. J. (1986). Seasonal production of photosynthetic picoplankton and nanoplankton in the Celtic Sea. Mar. Ecol. Prog. Ser. 28: 251-258

Jolley, E. T., Jones, A. K. (1977). The interaction between Navicula muralis Grunow and an associated species of Flavobacterium. Br. phycol. J. 12: 315-328

Jones, R. W., Wild, D. G. (1973). Regulation of uptake of purines, pyrimidines and amino acids by Candida utilis. Biochem. J. 134: 617-627

Jørgensen, N. O. G. (1982). Heterotrophic assimilation and occurance of dissolved free amino acids in a shallow estuary. Mar. Ecol. Prog. Ser. 8: 145-159

Jørgensen, N. O. G., Mopper, K., Lindroth, P. (1980). Occurance, origin and assimilation of free amino acids in an estuarine environment. Ophelia suppl. 1: 179-192

Jørgensen, N. O. G., Søndergaard, M. (1984). Are dissolved free amino acids free? Microb. Ecol. 10: 301-316

Kirchman, D., Hodson, R. E. (1984). Inhibition by peptides of amino acid uptake by bacterial populations in natural waters: Implications for the regulation of amino acid transport and incorporation. Appl. environ. Microbiol. 47: 624-631

Kirchman, D. L., Hodson, R. E. (1986). Metabolic regulation of amino acid uptake in marine waters. Limnol. Oceanogr. 31: 339-350

Kirk, D. L., Kirk, M. M. (1978a). Carrier-mediated uptake of 
arginine and urea by Chlamydomonas reinhardtii. $\mathrm{Pl}$. Physiol. 61: 556-560

Kirk, D. L., Kirk, M. M. (1978b). Amino acid and urea uptake in ten species of chlorophyta. J. Phycol. 14: 198-203.

Kirk, M. M., Kirk, D. L. (1978). Carrier-mediated uptake of arginine and urea by Volvox carteri t. nagariensis. Pl. Physiol. 61: 549-555

Laanbroek, H. J., Verplanke, J. C., de Visscher, P. R. M., de Vuyst, R. (1985). Distribution of phyto- and bacterioplankton growth and biomass parameters, dissolved inorganic nutrients and free amino acids during a spring bloom in the Oosterschelde basin, The Netherlands. Mar. Ecol. Prog. Ser. 25: 1-11

Landymore, A. F., Antia, N. J. (1977). Growth of a marine diatom and a haptophycean alga on phenylalanine or tyrosine serving as sole nitrogen source. J. Phycol. 13: $231-238$

Larsson, U., Hagström, A. (1979). Phytoplankton exudate release as an energy source for the growth of pelagic bacteria. Mar. Biol. 52: 199-206

Laws, E. A., Harrison, W. G., DiTullio, G. R. (1985). A comparison of nitrogen assimilation rates based on ${ }^{15} \mathrm{~N}$ uptake and autotrophic protein synthesis. Deep Sea Res. 32: $85-95$

LeBouteiller, A. (1986). Environmental control of nitrate and ammonium uptake by phytoplankton in the equatorial Atlantic Ocean. Mar. Ecol. Prog. Ser. 30: 167-179

Lee, C., Bada, J L. (1977). Dissolved amino acids in the equatorial Pacific, the Sargasso Sea, and Biscayne Bay. Limnol. Oceanogr. 22: 502-510

Lewin, J. C. (1963). Heterotrophy in marine diatoms. In: Oppenheimer, C. H. (ed.). Symposium on marine microbiology. Charles C. Thomas Publishing. Springfield, Illinois, p. 229-235

Lewin, J. C., Hellebust, J. A. (1970). Heterotrophic nutrition of the marine pennate diatom, Cylindrotheca fusiformis. Can. J. Microbiol. 16: 1123-1129

Lewin, J., Hellebust, J. A. (1975). Heterotrophic nutrition of the marine pennate diatom Navicula pavillardi Hustedt. Can. J. Microbial. 21: 1335-1342

Lewin, J., Hellebust, J. A. (1976). Heterotrophic nutrition of the marine pennate diatom Nitzschia angularis var. affinis. Mar. Biol. 36: 313-320

Lewin, J. Hellebust, J. A. (1978). Utilization of glutamate and glucose for heterotrophic growth by the marine pennate diatom Nitzschia laevis. Mar. Biol. 47: 1-7

Lewin, J. C., Lewin, R. A. (1960). Auxotrophy and heterotrophy in marine littoral diatoms. Can. J. Microbiol. 6: $127-134$

Lewin, J., Lewin, R. A. (1967). Culture and nutrition of some apochlorotic diatoms of the genus Nitzschia. J. gen. Microbiol. 46: 361-367

Li, W. K. W. Dickie, P. M. (1985). Metabolic inhibition of sizefractionated marine plankton radiolabelled with amino acids, glucose, bicarbonate, and phosphate in the light and dark. Microb. Ecol. 11: 11-24

Lindroth, P., Mopper, K. (1979). High performance liquid chromatographic determination of sub-picomolar amounts of amino acids by precolumn fluorescence derivatisation with o-phaldialdehyde. Analyt. Chem. 51: 1667-1674

Litchfield, C. D. (1973). Interactions of amino acids and marine bacteria. In: Stevenson, L. H., Colwell, R. R. (ed.) Estuarine microbial ecology. University of South Carolina Press, Columbia, p. 145-168

Liu, M. S., Hellebust, J. A. (1974a). Uptake of amino acids by the marine centric diatom Cyclotella cryptica. Can. J. Microbiol. 20; 1109-1118
Liu, M. S., Hellebust, J. A. (1974b). Utilization of amino acids as nitrogen-sources, and their effects on nitrate reductase in the marine diatom Cyclotella cryptica. Can. J. Microbiol. 20: 1119-1125

Liu, M. S., Hellebust, J. A. (1976a). Effects of salinity and osmolarity of the medium on amino acid metabolism in Cyclotella cryptica. Can. J. Bot. 54: 938-948

Liu, M. S., Hellebust, J. A. (1976b). Regulation of proline metabolism in the marine centric diatom Cyclotella cryptica. Can. J. Bot. 54: 949-959

Lu. M., Stephens, G. C. (1984). Demonstration of net influx of free amino acids in Phaeodactylum tricornutum using high performance liquid chromatography. J. Phycol. 20: 584-589

McCarthy, J. J. (1972). The uptake of urea by natural populations of marine phytoplankton, Limnol. Oceanogr 17: 738-748

McCarthy, J. J. (1981). Uptake of major nutrients by estuarine plants. In: Neilson, B. J., Cronin, L. E. (ed.). Estuaries and nutrients. Humana Press Clifton, New Jersey, p. 139-163

McCarthy, J. J., Eppley, R. W. (1972). A comparison of chemical, isotopic and enzymatic methods for measuring nitrogen assimilation of marine phytoplankton. Limnol. Oceanogr. 17: 371-382

McCarthy, J. J., Goldman, J. C. (1979). Nitrogenous nutrition of marine phytoplankton in nutrient depleted waters. Science 203: 670-672

McCarthy, J. J., Taylor, W. R., Taft J. L. (1975). The dynamics of nitrogen and phosphorus cycling in the open waters of the Chesapeake Bay. In: Church, T. M. (ed.) Marine chemistry in the coastal environment. ACS Symposium Series, Washington, D. C., No. 18, p. 664-681

McCarthy, J. J., Taylor, W. R., Taft, J. L. (1977). Nitrogenous nutrition of the plankton in the Chesapeake Bay. I. Nutrient availability and phytoplankton preference. Limnol. Oceanogr. 22: 996-1011

McLean, R. O., Corrigan, J., Webster, J. (1981). Heterotrophic nutrition in Melosira nummuloides, a possible role in affecting distribution in the Clyde Estuary. Br. phycol. J. 16: 95-106

Mague, T. H., Friberg, E., Hughes, D. J., Morris, I. (1980). Extracellular release of carbon by marine phytoplankton; a physiological approach. Limnol. Oceanogr. 25: 262-279

Ming, L., Stephens, G. C. (1985). Uptake of free amino acids by the diatom Melosira mediocris. Hydrobiologia 128 : $187-191$

Mopper, K., Dawson, R. (1986). Determination of amino acids in sea water - Recent chromatographic developments and future directions. Sci. Total Environ. 49: 115-131

Mopper, K., Lindroth, P. (1982). Diel and depth variations in dissolved free amino acids and ammonium in the Baltic Sea determined by shipboard HPLC analysis. Limnol. Oceanogr 27: 336-347

Morris, I. (1974). Nitrogen assimilation and protein synthesis. In: Stewart, W D. P. (ed.). Algal physiology and biochemistry. Blackwell Scientific Publ., Oxford, p. 583-609

Morris, I. (ed.) (1980). The physiological ecology of phytoplankton. Blackwell Scientific Publ., Oxford

Morrison, C. E., Lichstein, H. C. (1976). Regulation of lysine transport by feedback inhibition in Saccharomyces cerevisiae. J. Bacteriol. 125: 864-871

Myklestad. S. Sakshaug, E. (1983). Alkaline phosphatase activity of Skeletonema costatum populations in the Tronheims Fjord Norway. J. Plankton Res. 5: 557-564

Neilson, A. H., Larsson, T. (1980). The utilization of organic 
nitrogen for growth of algae: Physiological aspects. Physiologia Pl. 48: 542-553

Neilson, A. H., Lewin, R. A. (1974). The uptake and utilization of organic carbon by algae: An essay in comparative biochemistry. Phycologia 13: 227-264

Newell: B. S., Dalpont, G., Grant, B. R. (1972). The excretion of organic nitrogen by marine algae in batch and continous culture. Can. J. bot. 50: 2605-2611

North, B. B. (1975). Primary amines in California coastal waters: Utilization by phytoplankton. Limnol. Oceanogr 20: $20-27$

North, B. B., Stephens, G. C. (1967). Uptake and assimilation of amino acids by Platymonas. Biol. Bull mar. biol. Lab., Woods Hole 133: 391-400

North, B. B., Stephens, G. C. (1971). Uptake and assimilation of amino acids by Platymonas. II. Increased uptake in nitrogen-deficient cells. Biol. Bull. mar biol. Lab., Woods Hole 140: 242-254

North, B. B., Stephens, G. C. (1972). Amino acid transport in Nitzschia ovalis Arnott. J. Phycol. 8: 64-68

Palumbo, A. V., Ferguson, R. L., Rublee, P. A. (1983). Efficient utilization of dissolved free amino acids by suspended marine bacteria. J. exp. mar. Biol. Ecol. 69: 257-266

Paul, J. H. (1983). Uptake of organic nitrogen. ln: Carpenter, E. J., Capone, D. G. (ed.). Nitrogen in the marine enviroment. Academic Press Inc., London, p. 275-308.

Pederson, A. G., Knutsen, G. (1974). Uptake of L-phenylalanine in synchronous Chlorella fusca. Characterisation of the uptake system. Physiologia, Pl. 32: 294-300

Pettersen, R. (1975). Control by ammonium of inter-compartmental guanine transport in Chlorella. Z. PflPhysiol. 76: 213-223

Pettersen, R., Knutsen, G. (1974). Uptake of guanine by synchronized Chlorella fusca: Characterization of the transport system in autospores. Arch. Mikrobiol. 96: $233-246$

Platt, T. (ed.) (1981). Physiological bases of phytoplankton ecology. Can. Bull. Fish. Aquat. Sci. 210

Platt, T., Subba-Rao, D. V., Irvin, B. (1983). Photosynthesis of picoplankton in the oligotrophic ocean. Nature, Lond. 301: 702-704

Pomeroy, L. R. (1980). Detritus and its role as a food source. In: Barnes, M. S. K., Mann, K. H. (ed). Fundamentals of aquatic ecosystems. Blackwell Scientific Publ., Oxford, p. $84-102$

Poulet, S. A., Martin-Jézéquel, V. (1983). Relationships between dissolved free amino acids, chemical composition and growth of the marine diatom Chaetoceros debile. Mar. Biol. 77: 93-100

Poulet, S. A., Martin-Jézéquel, V., Delmas, D. (1985). Gradient of dissolved free amino acids and phytoplankton in a shallow bay. Hydrobiologia 11: 11-17

Poulet, S. A., Martin-Jézéquel, V., Head, R. N. (1984). Distribution of dissolved free amino acids in the Ushant front region. Mar. Ecol. Prog. Ser. 18: 49-55

Provasoli, L., McLaughlin, J. J. A. (1963). Limited heterotrophy of some photosynthetic dinoflagellates. In: Oppenheimer, C. H. (ed.). Marine microbiology. Charles C. Thomas Publishing, Springfield, Illinois, p. 105-113

Provasoli, L., McLaughlin, J. J. A., Droop. M. R. (1957). The development of artifical media for marine algae. Arch. Mikrobiol. 25: 392: 428

Raven, J. A. (1980). Nutrient transport in microalgae. Adv. microb. Physiol. 21: 47-226

Redfield, A. C. (1958). The biological control of chemical factors in the enviroment. Am Scient. 46: 205-221
Remsen, C. C. (1971). The distribution of urea in coastal and oceanic waters. Limnol. Oceanogr. 16: 732-740

Remsen, C. C., Carpenter, E. J., Schroeder, B. W (1972). Competition for urea among estuarine micro-organisms. Ecology 53: 921-926

Remsen, C. C., Carpenter, E. J., Schroeder, B. W. (1974). The role of urea in marine microbial ecology. In: Colwell, R. R., Morita, R. Y. (ed.). Effect of the ocean environment on microbial activities. University Park Press, Baltimore, p. 286-304

Richards, L., Thurston, C. F. (1980). Uptake of leucine and tyrosine and their intracellular pools in Chlorella fusca var vacuolata. J. gen. Microbiol. 121: 39-47

Riley, J. P., Segar, D. A. (1970). The seasonal variation of the free and combined dissolved amino acids in the Irish Sea. J. mar. biol. Ass. U. K. 50: 713-720

Roman, M. R. (1983). Nitrogenous nutrition of marine invertebrates. In: Carpenter, E. J., Capone, D. G. (ed.). Nitrogen in the marine environment. Academic Press Inc., London, p. $347-384$

Royal Society Study Group (1983). The nitrogen cycle of the United Kingdom. The Royal Society, London

Ryther, J. H., Dunstan, W. M. (1971). Nitrogen, phosphorus and eutrophication in the coastal marine environment. Science 171: 1008-1013

Ryther, J. H., Sanders, J. G. (1980). Experimental evidence of zooplankton control of the species composition and size distribution of marine phytoplankton. Mar. Ecol. Prog. Ser. 3: $279-283$

Saks, N. M. Kahn, E. G. (1979). Substrate competition between a salt marsh diatom and a bacterial population. J. Phycol. 15: 17-21

Sauer, N., Komor, E., Tanner, M. (1983). Regulation and characterization of two inducible amino acid transport systems in Chlorella vulgaris. Planta 159: 404-410

Schell, D. M. (1974). Uptake and regeneration of free amino acids in marine waters of Southoust Alaska. Limnol. Oceanogr 19: 260-270

Sepers, A. B. J. (1981). Diversity of ammonifying bacteria. Hydrobiologia 83: 343-350

Shah, N., Syrett, P. J. (1982). Uptake of guanine by the diatom Phaeodactylum tricornutum. J. Phycol. 18: 579-587

Shah, N., Syrett, P. J. (1984). The uptake of guanine and hypoxanthine by marine microalgae. J. mar. biol. Ass. U. K. $64: 545-556$

Sharp, J. H. (1977). Excretion of organic matter by marine phytoplankton: Do healthy cells do it? Limnol. Oceanogr. 22: $381-397$

Sloan, P. R., Strickland, J. D. H. (1966). Heterotrophy of four marine phytoplankters at low substrate concentrations. $J$. Phycol. 2: 29-32

Smith, D. C., Bassham, J. A., Kirk, M. (1961). Dynamics of the photosynthesis of carbon compounds. II. Amino acid synthesis. Biochim. biophys. Acta. 48: 299-313

Smith, S. V. (1984). Phosphorus versus nitrogen limitation in the marine environment. Limnol. Oceanogr. 29: 1149-1160

Smith, S. V., Kimmerer, W. J., Walsh, T. W. (1986). Vertical flux and biogeochemical turnover regulate nutrient limitation of net organic production in the North Pacific Gyre. Limnol. Oceanogr. 31: 161-167

Soldo, A. T., Godoy, G. A., Larin, F. (1978). Purine-excretory nature of refractile bodies in the marine ciliate Parauranema acutum. J. Protozool. 25: 416-418.

Stephens, G. C., North, B. B. (1971). Extrusion of carbon accompanying uptake of amino acids by marine phytoplankters. Limnol. Oceanogr 16:752-757 
Syrett, P. J. (1981). Nitrogen metabolism of microalgae. In Platt, T (ed.). Physiological bases of phytoplankton ecology. Can. Bull. Fish. Aquat. Sci. 210: 182-210

Syrett, P. J., Morris, I. (1963). The inhibition of nitrate assimilation by ammonium in Chlorella. Biochim. biophys. Acta. 67: $566-575$

Syrett, P. J., Flynn, K. J., Molloy, C. J., Dixon, G. K, Peplinska, A. M., Cresswell, R. C. (1986). Effects of nitrogen deprivation on rates of uptake of nitrogenous compounds by the diatom Phaedactylum tricornutum Bohlin. New. Phytol. 102: 39-44

Thomas, W. H. (1966). Surface nitrogenous nutrients and phytoplankton in the northeastern tropical Pacific Ocean. Limnol. Oceanogr. 11: 393-400

Turley, C. M. (1985). Biological studies in the vicinity of a shallow-sea tidal mixing front IV Seasonal and spatial distribution of urea and its uptake by phytoplankton. Phil. Trans. R. Soc. 310: 471-500

Turner, M. F. (1979). Nutrition of some marine microalgae with special reference to vitamin requirements and utilization of nitrogen and carbon sources. J. mar. biol. Ass. U. K. 59: 535-552

Verity, P. G. (1985). Ammonium excretion rates of oceanic copepods and implications for estimates of primary production in the Sargasso Sea. Biol. Oceanogr. 3: 249-283

Webb, K. L., Johannes, R. E. (1967). Studies of the release of dissolved free amino acids by marine zooplankton. Limnol. Oceanogr, 12; 376-382

Webb, K. L, Johannes, R. E., Coward, S. J. (1971). Effects of salinity and starvation on release of dissolved free amino acids by Dugesia dorotocephala and Bdelloura candida (Platyhelminthes, Turbellaria). Biol. Bull. mar. biol. Lab., Woods Hole 141: 364-371

Wheeler, P. A. (1977). Effect of nitrogen source on Platymonas (Chlorophyta) cell composition and amino acid uptake rates. J. Phycol. 13: 301-303

Wheeler, P. A. (1983). Phytoplankton nitrogen metabolism. In: Carpenter, E. J., Capone, D. G. (ed.). Nitrogen in the marine environment. Academic Press Inc., London, p. 309-346

Wheeler, P. A., North, B. B., Littler, M. M., Stephens, G. C. (1977). Uptake of glycine by natural phytoplankton communities. Limnol Oceanogr. 22: 900-910
Wheeler, P. A., North, B. B., Stephens, G. C. (1974). Amino acid uptake by marine phytoplankters. Limnol. Oceanogr 19: 249-259

Wheeler, P. A., Stephens, G. C. (1977). Metabolic segregation of intracellular free amino acids in Platymonas (Chlorophyta). J. Phycol. 13: 193-197

White, A. W. (1974). Uptake of organic compounds by two facultatively heterotrophic marine centric diatoms. J. Phycol. 10: $433-438$

White, A. W., Shilo, M. (1975). Heterotrophic growth of the filamentous blue-green alga Plectonema boryanum. Arch. Microbiol. 102: 123-127

Williams, P. J. LeB. (1970). Heterotrophic utilization of dissolved organic compounds in the sea. I. Size distribution of population and relationship between repiration and incorporation of growth substrates. J. mar. biol. Ass. U. K. 50: $859-870$

Williams, P. J. LeB. (1975). Biological and chemical aspects of dissolved organic material in sea water. In: Riley, J. P., Skirrow, G. (ed.). Chemical oceanography, Vol. 2, 2nd edn. Academic Press Inc., London, p. 301-364

Williams, P. J. LeB., Gray, R. W. (1970). Heterotrophic utilization of dissolved organic compounds in the sea. II. Observations on the responses of heterotrophic marine popula. tions to abrupt increases in amino acid concentration. $\mathrm{J}$. mar. biol. Ass. U. K. 50: 871-881

Williams, P. J. LeB., Yentsch, C. S. (1976). An examination of photosynthetic production, excretion of photosynthetic products, and heterotrophic utilization of dissolved organic compounds with reference to results from a coastal subtropical sea. Mar. Biol. 35: 31-40

Williams, R., Poulet, S. A. (1986). Relationship between the zooplankton, phytoplankton, particulate matter and dissolved free amino acids in the Celtic Sea I. Unstratified water conditions. Mar. Biol. 90: 279-284

Wolter, K. (1982). Bacterial incorporation of organic substances released by natural phytoplankton populations. Mar. Ecol. Prog. Ser. 7: 287-295

Yamada, M., Arai, Y., Tsuruta, A., Yoshida, Y (1983). Utilization of organic nitrogenous compounds as nitrogen sources by marine phytoplankton. Bull. Jap. Soc. scient. Fish. 49: 1445-1448 (English abstract and tables) 